\title{
التهكم التنظيمي لدى أعضاء هيئة التدريس بجامعة القاهرة دراسة تحليلية نقدية
}

\author{
د. / فاروق جعفر عبالحكيم مرزوق \\ أستاذ مساعد - كلية الدراسات العليا للتربية

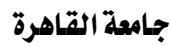

هدفت الدراسة لتعرف التهكم التنظيهي، وأبعاده، وتحديد واقعه بجامعة القاهرة من وجهة نظر

أعضاء هيئة التندبي، وتقديم بعض التوصيات والدقترحات لتقليل التهكم التتظبي في جامعة القاهرة.

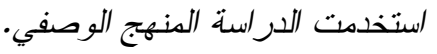

وخلصت نتائج الدراسة إلى أن محاور الأداة قد تحقتت من وجهة نظر عبنة الدراسة بدرجات

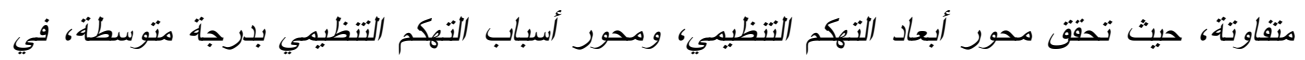

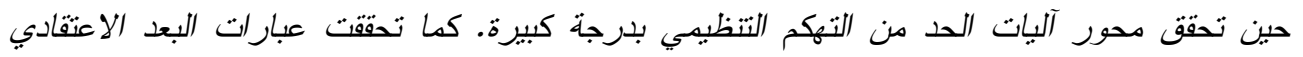

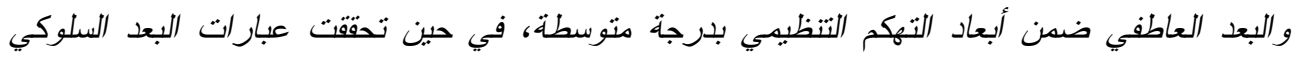

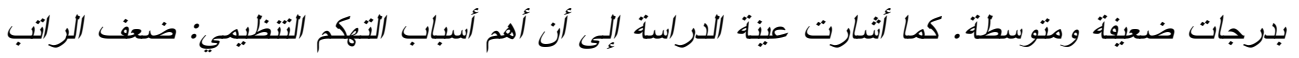

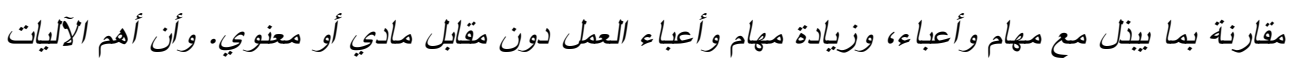

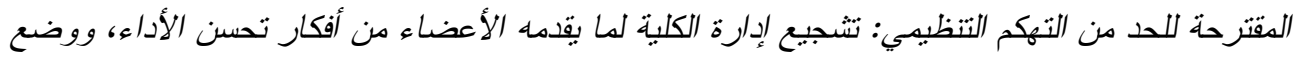

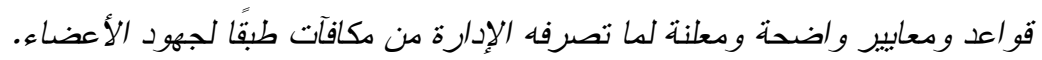

الكلمات المفتاحية : التهكم التنظيمي- جامعة القاهرة.

\section{Abstract}

The study aimed to identify organizational Cynicism, its dimensions, and to determine the occurrence of Cairo University from the viewpoint of the teaching members, and to provide some recommendations and proposals to reduce organizational Cynicism at Cairo university. The study used the descriptive approach.

The results of the study noted that the tool's axes have been achieved from the viewpoint of the study sample in varying degrees, as the axis of organizational Cynicism has been achieved at a moderate degree, while the axis of mechanisms to reduce organizational Cynicism has been achieved significantly.

Phrases of belief dimension were achieved within the dimensions of Organizational Cynicism in a moderate degree, while phrases of behavioral 
dimension were achieved in a weak and medium degree, while expressions of emotional dimension were achieved in a medium degree. The study sample also indicated that the most important causes of organizational cynicism are: weak salary compared to what is being done from tasks and burdens, and increasing work tasks and workloads Without financial or moral compensation. And the most important mechanisms proposed to reduce organizational Cynicism: Encouraging the faculty administration for the members to improve performance, and announced rules and standards For the remuneration that the administration pays in accordance with. The efforts of the members .

The keywords : Organizational Cynicism - Cairo University.

و التميز في الأداء. إن التحدي الذي يواجـهـ

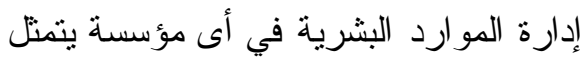

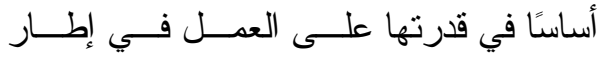
الاستر اتيجية و الأهداف العامة للمؤسسة مــن

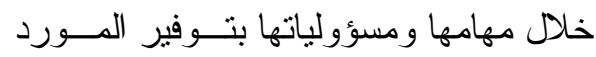
البشري بناء على احتياجاتها، و الأهم من ذلك

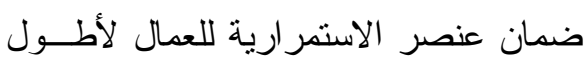

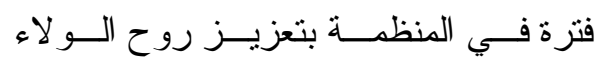

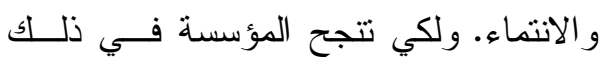
عليها بتبني حزمة من الأسس في ممارساتها

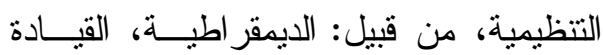

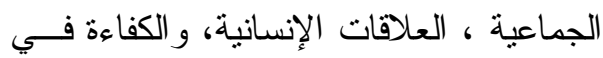
الأداء، وتقدير العـاملين و الأســماع إلـى لـى وجهات نظرهم؛ وبذللك تتجح المؤسسة فـي وني رفع الحواجز بين الرئيس ومرؤوسيه ويشعر

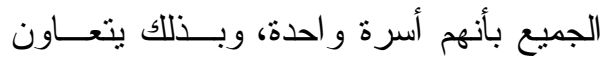

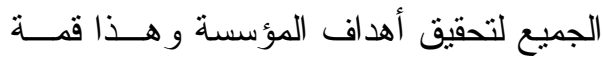
النجاح بالنسبة لها.
شهـد العالم خــلال العقــود الأخيــرة

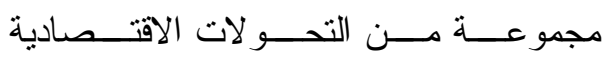

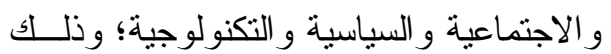
بفعل قوي ومتغير ات شديدة التأثير من قبيــلــلـيل العولمة وتكنولوجيا المعلومات، و التي كــان

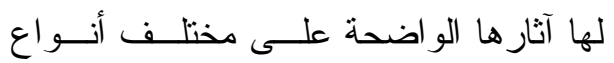
المؤسسات، بما جعلهـا تمــارس أنـشطتها

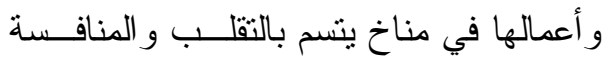

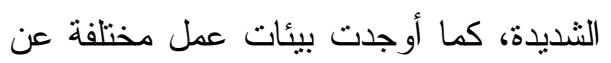
تلك التي سادت في الماضي. وفي ظــلـل اثـــنداد المنافـسة بــين المؤسسات عامة، و المؤسـسـات التعليميــة

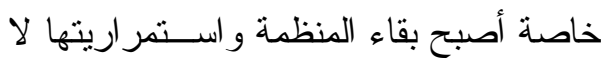
يتوقف على توفر الموارد المالية و التكنولوجية

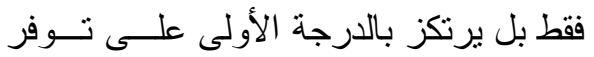
العنصر البشري الذي لا يتميز فقط بالقدر ات

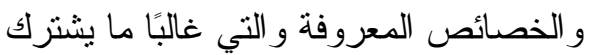

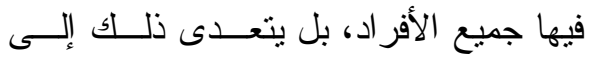
الصفات التي تحقق فيها المؤسـسـة الجــودة التهات 
في أهداف المنظمة) Cagdas Caz \&Sait

.(Bardakci,2019, 349

فالفرد الذي يشعر بالارتياح و الرضــــا

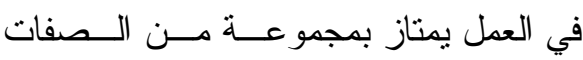

و المؤشر ات السلوكية التي تعتبر دليلاً و اضحًا

عن رضـاه تجاه مختلف عو امـلـل و مكونـــات

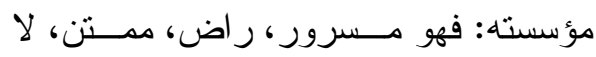

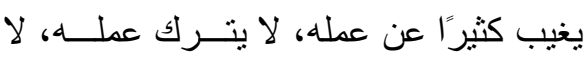

يستغل الموارد و المواد في مؤسسته، يبنـي لئي

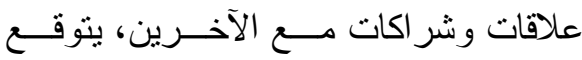

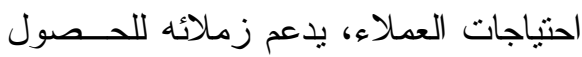
على مستوى عمل مميز ، يأخذ زمام المبادرة،

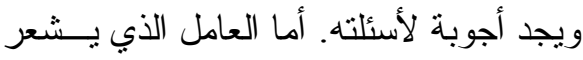
بقلة الرضا في العمل، نظهـــر عليـــهـ أيــضـا

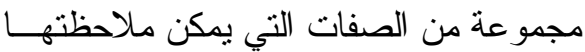

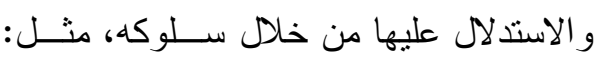

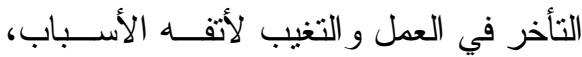
الصر اع مع الــزملاء، وكتــرة الــشكاوي و التظلمات، انخفاض الروح المعنويـــة فــي العمل، انخفاض وتيرة العمل، انخفاض معدل

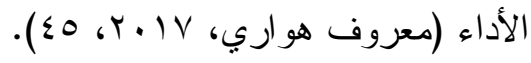
إن ضعف الالتز ام في العمل يعبر عنه بمجموعة من السلوكيات التى تــضر بيئـــة العمل، ومنتل هذه التصرفات ووسائل التعبير

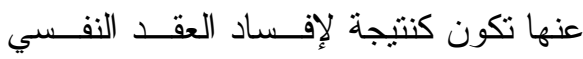
Psychological contract

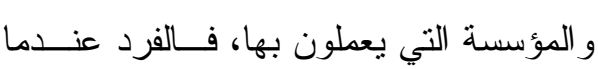

وتــــرتبط قــــوة المؤســـسات - أى

مؤسسة- بشكل معقد بأفر ادها الذين يركزون على مهامهم ويوظفون قدر اتهم و إمكانــاتهم بشكل فعال للغاية في سبيل ذللك، إلا أن هذه وانه الجهود و المهار ات ليست كافية في حد ذاتها خاصة عندما نفكر في اســتامة المؤسـسـة.

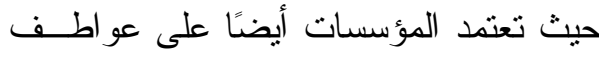

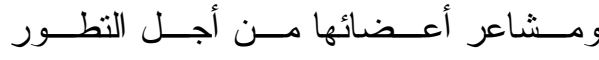
والحصول على فعالية أكبر وتحقيق الأهداف

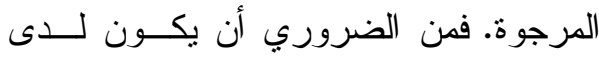
الأعضاء مشاعر ومو اقـــ إيجابيــة تجــاه مجالات العمل بالمؤسسة من جهة، وتجـــاه

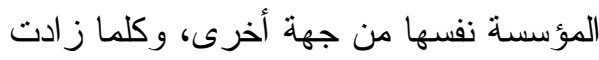

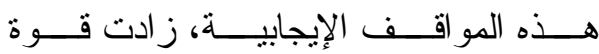

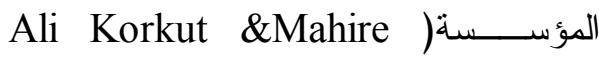
.(Aslan,2016, 95

حيث تعد المؤسسات بمثابــة هياكــل معقدة يتم إنشاؤ ها لتحقيق هدف معين، ولكي تتجح في تحقيق أهدافها، يجــب أن يعتبــــر

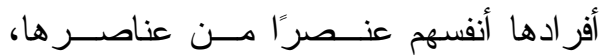
ويشتركو ا مع مؤسستهم في تحديد أهـــدافها، بما بساعد على وجود أرضية مشتركة بينهم؛ لكي تعمل المؤسسة بكفاءة، من خلال تحديد

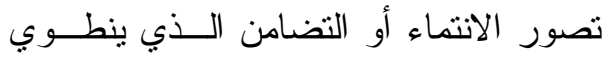

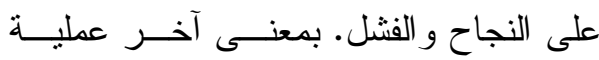

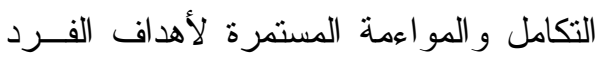


و الانتقاد الموجهة للمؤسسة و الذي يتماثىى مع

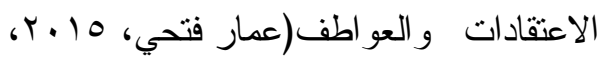

ويرتبط التهكم التنظيمي بالـسلوكيات

المنحرفة في العمل؛ حيث إن التهكم التتظيمي

و السلوكيات غير الأخلاقية و المنحرفة نتكل فئل

مصدر قلق كبير للمؤسسات، إذ ينبغي عليها

إيجاد الحلول لمو اجهة هذه المشكلة؛ لغرض

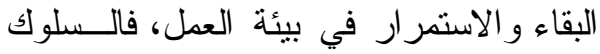

السلبي المتمنل بالسلوك المنحرف للعــاملين ينبثق نتيجة الموقف السلبي(التهكم التتظيمي).

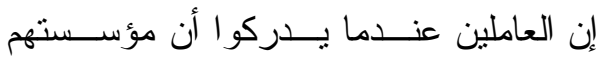
وممارساتها التنظيمية وممارسات المــديرين

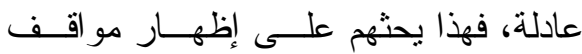
وسلوكيات إيجابية تجاه المؤسسة ومديريها، في حين أنه عندما يشعرون أن مؤستتهم غير عادلة فهذا يحثُهم على إظهار سلوكيات سلبية ضد المؤسسة و المديرين( Ahmed. W\& et

$$
\text { .(al,2013,149 }
$$

وظاهرة التهكم التتظيمي وثثقة الصلة

بظاهرة الاغتراب الوظيفي، و التــي تعبــر

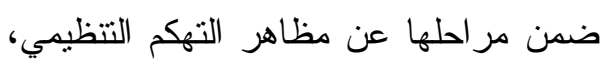

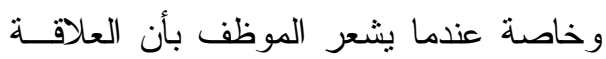

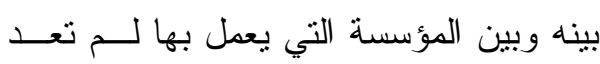
طبيعية وأنه أصبح يسودها شيء من التونز ،

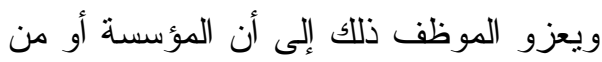
يقومون بتمثيلها أصبح لديهم موقةً الــا سـلبيًا
يلتحق بالعمل في أى مؤسسة تــصبح لديـــا

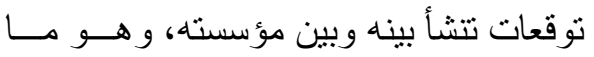
يعرف بالعقد النفسي، وهو عقد ضمنى بــين الفرد و المؤسسة، يحدد ما بتوقع أن يقدمه أو بعدي بيتلقاه كل طرف من الآخر ، ونتيجة الوفاء بهذا

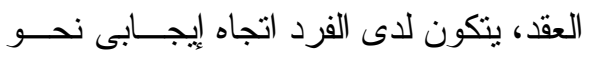

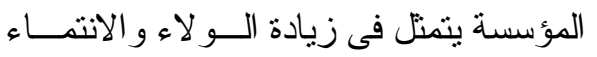

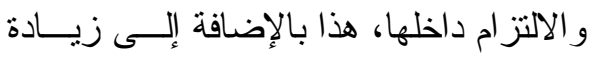

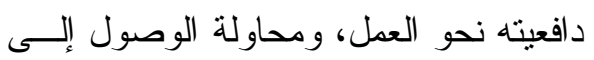

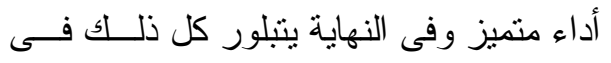

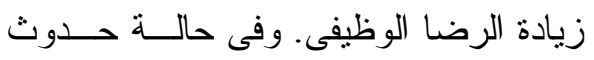
إخلال أو خرق للعقد النفسى يكون ذلك دائمًا

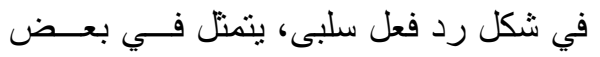
السلوكيات الضارة منها عدم الالتز ام في مكان

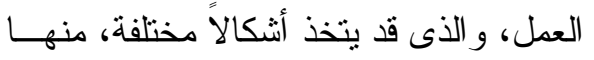

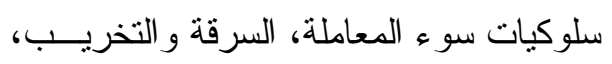

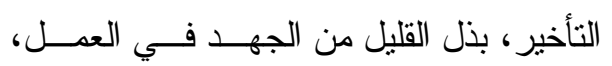

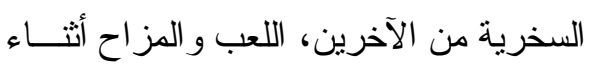

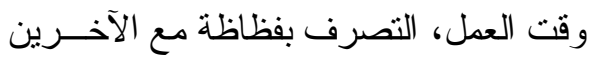

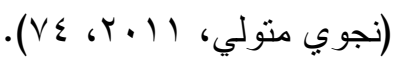

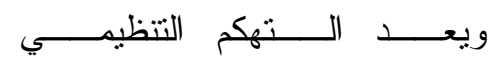
Organizational Cynicism يتكون لدى العاملين نحـــو المؤســـة التــي

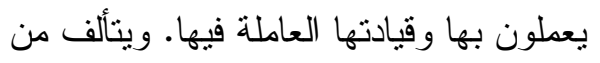

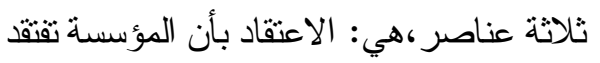
إلى الاستقامة و النز اهة، و عو اطف سلبية تجاه

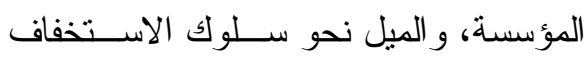


مؤسستهم تفتقد للمصداقية حيث ثقول شــيء وتفعل شــيء آخــر، كمـــا أن ممارســاتها

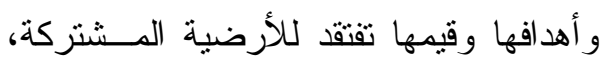
مما بسهر في توليد مشاعر عاطفيـة ســيئة تعبر في أغلب الأحيان عن الإحباط و التشائم و القلق ، وتظهــر فــي ســلـوكيات التــــر و السخرية والتشكي بين الأفــر اد العــــلين. و هو ما دعمته نتائج در استة(سحر عنــاوي، צ ا • r)، و التي خلصت إلى وجود ارتبــاط إيجابي بين عدالة الإجــر اءات و التعــاملات داخل المؤسسات وبين شعور الأفر اد العاملين بالانتماء و الو لاء لمؤسساتهج . أما در استة(علاء فرحــان وآخــرون، צ ا • Y)، فقد ربطت نتائجها بين تأثير وجود التهكم التتظيمي وفنثل محـــاو لات التغييــر

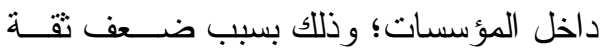
العاملين ببر امج التغبير المعدة من قبل الإدارة العليا أو الخوف من أن هذه البر امج قد تضر بمصالحهم أو عدم وضوح الأهداف الخاصة

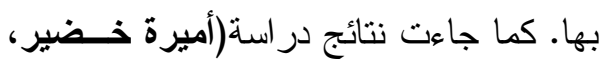
צ 1 • (Y)، في نفس المسار وأشنارت إلـى أن قلة التدريب و التعليم تجعــل الأفــر اد غيــر مستعدين بشكل جيد لتأدية الأعمال المنوطــة بهم، كما أن أهداف العمل تكون مبههة وغير و اضحة، مما يؤدي إلى تهكمهم. و هـــو مـــا

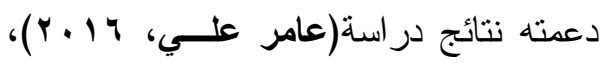
من أن العاملين عندما يدركو ا أن مبــادرات
تجاهه، و أنه لم يعد له نفس القدر من الأهمية الوظيفية و المنزلة الاجتماعية، ومن ثَم يبـــــأ في التهكم التنظيمي على مؤسسته (منــصور

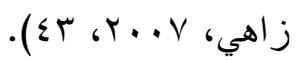
ولـسلوك الــتهكم التتظيهـي الــذي تتعرض لله المؤسسات و المديرين العديد من النتائج السلبية؛ حيث إنــهـ بـــدمر التعــاون و التو اصل و الإبداع و السلاحم و التقـــة داخــلـ المؤسسة بصفة عامة، و المؤسسة التعليميــة

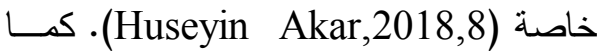
أظهرت نتائج الدراسات التي ركزت علـىى

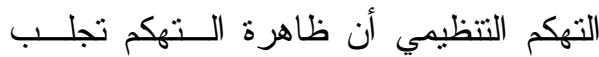
الكثثر من الآثـار الــضـارة علــى الأفــر اد و المؤسسات. حيث إن التهكم التتظيمي يعيق عملية الرضنا الوظيفي، و الالتز ام التتظيمـي، و المو اطنة التتظيمية، مما يؤدي إلى الإحباط Ali R1za Terzi \& ( في العمل والاغتر اب) .(Ramazan Derin,2016,195 ونظرًا لأهمبة ظاهرة التهكم التتظيمي في السياق المؤسسي وما يترنب عليها مسـن آثار تتعكس بالــسلب علــى أداء المؤسـسـة وكفاءتها، سعت الدراسة الحالية لتعرف موقع

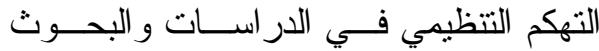
السابقة التي تصدت لتتاوله وبيان انعكاســاته على العمل المؤسسي. فقد أثثــارت نتــائج

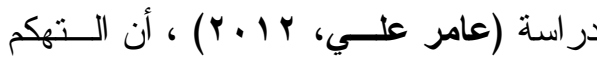
التتظيمي ينشط عنــدما يــدرك الأفــر اد أن 
در اسة (محمد مظهر، 11 + ب)، من أن شعور

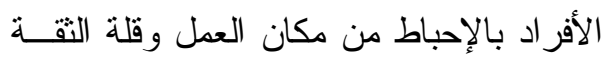
في دوافع الإدارة وضعف العلاقات الجيــدة

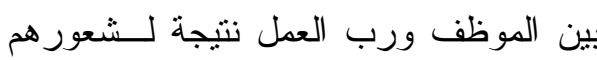
بانتهاك العقد النفسي من قبل رب العمل يزيد من مستوى تهكمه التتظيمي. و على صــعيد الدراســات الأجنبيــة جاءت نتائجها مؤكدة لنظبر اتها العربية، فقد

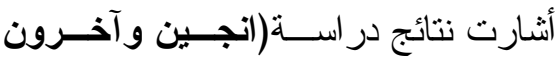

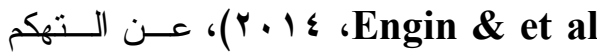
التنظيمي و آثاره السلبية بالمؤسسات التعليمية أن التهكم التنظيمــي يــؤثر علــى الثقافـــة المدرسية و التحصيل الدراسي بصورة سلبية.

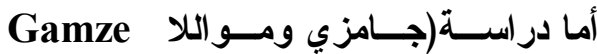
(Y) \&ualla

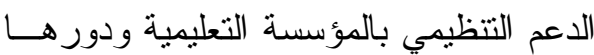
المهم في التقليل من مستوى التهكم التتظيمي. في حين ربطت نتائج در اسة (سلطان

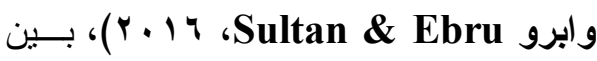
التمييز في العلاقات الاجتماعيــة و الــشؤون الإدارية بين المعلمين وتأثثيره علــى الــتهكم

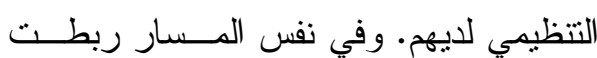

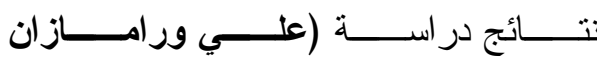
Ali\&Ramazan الديمقر اطية و التهكم التتظيمـي، فكلمـــا زاد ، مستوى القيادة الديمقر اطية من جانب مدر اء المدارس قل مستوى التهكم التتظيمي من قبل هن جالب
التغيير قد باءت بالفشل فان عو اطف سـلبية

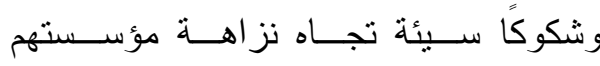

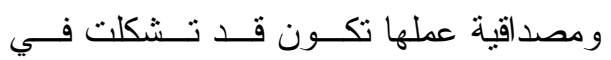

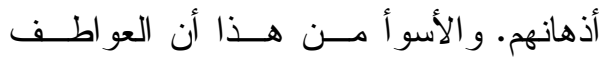
و المو اقف السلبية قد يتم تعميمها على جميـع

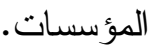
وهو ما أكدته نتائج در اسة (عبد الحكيم

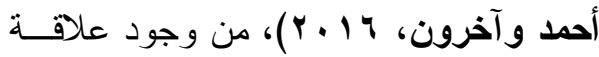
إيجابية بين الــتهكم التتظيـــي و الاغتــــاب الاجتماعي لدى الأفراد بمؤسساتهم. و أثنارت نتائج در استى (آرادن حامد وشهناز فاضل،

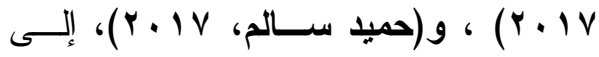
آليات تخفيف مستوى التهكم التنظيمي مسن خلال التركيز على الدعم التتظيمي و التو افق المهني لدى العاملين، بما يرفع من مسنوى

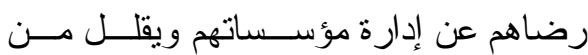
مستوى التهكم و السخرية كأثز ســلبي غيـــر مرغوب فيه و لا يخدم أهداف المؤسسة. كما

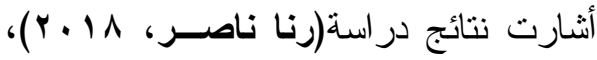

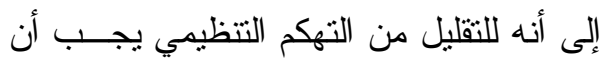
تبتعد ممارسة بعض القيادات الإداريـــة عــن لــن

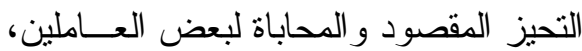
وضعف العدالة في نظم المكافآت وبــــر امج التدريب وتوزيع المهام و المسؤوليات؛ لكون تلاك الممارسات تسهم بشكل كبير في بلورة ظاهرة الــــكمم التتظيهـي للعـــاملين تجــــاه مؤســستهم • و هـــو مــــا دعمتــــه نتـــائج 


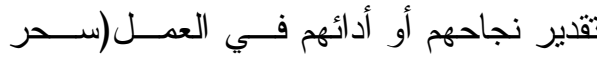

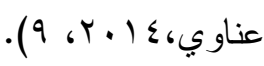

ويعد التهكم التنظيمي مشكلة نواجـهـ

المؤسسات كافة، و الجامعة كمؤسسة أكاديمية قد تواجه أيضًا ظاهرة التهكم التتظيمي بــين

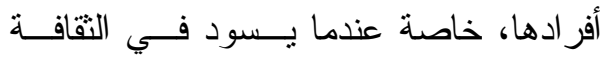

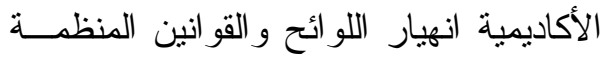

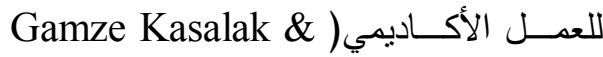
.(Mualla Bilgin,2014,126 وثمة علاقة بــين ظـــاهرة الــتهكم التتظيمي وضغوط العمل؛ حيث يعد الــتهكم من ضمن المستويات النفسية المعبــرة عـنـ

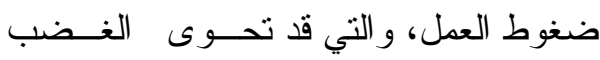
وتغيير تعابير الوجه، الألم النفسي والجسدي،

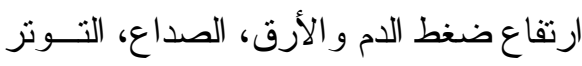

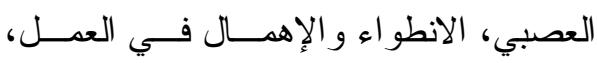

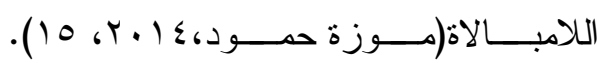
فالمو اقف المجهدة في العمل يمكن أن تــؤثز

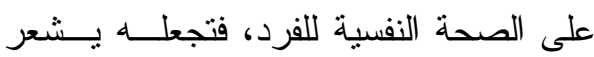
بمشاعر سلبية كتقلب المـزاج و العـصبية،

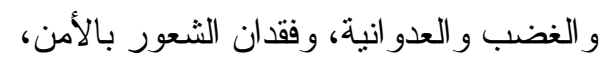

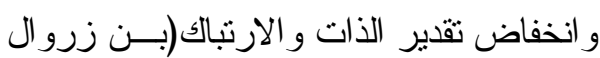

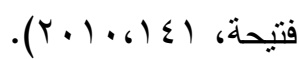

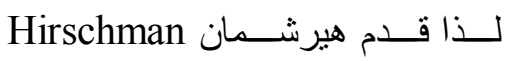
مفهوم صوت العاملين في عام • 19V خلال

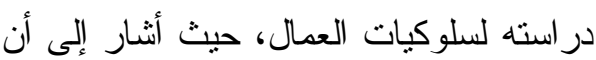

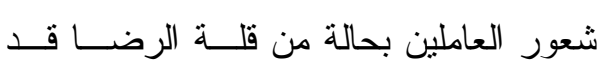

المعلمين، و العكس صحيح. و هو ما دعمتــه

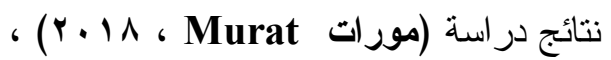
من التــأثير الإيجــابي لــسلوكيات العدالـــة التنظيمية على انخفــاض مـستوى الــتهكم التنظيمي.

في حين أثنارت نتائج دراسة (سيفيم

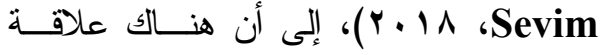

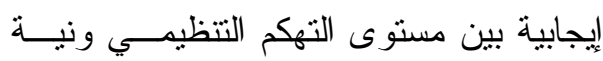

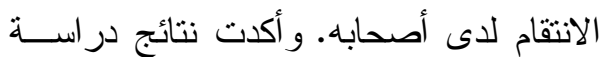
( حسيان وتايار Hüseyin \& Tayyar )

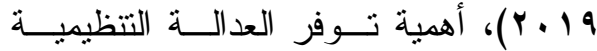
بالمؤسسة التعليميــة؛ حبـــث إن تـصور ات المعلمين للعدالة التنظيمية لها تأثثر قوي على لئ

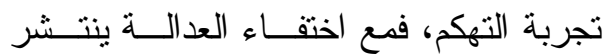
التهكم التنظيمي.

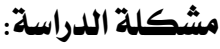

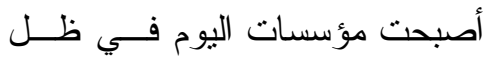

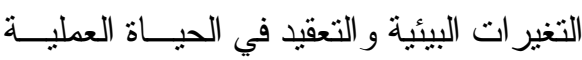
و انحلال القيم، و الفجوة بين التوقعات الفردية

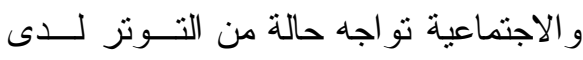
الأفر اد، و التي ربما في المدى البعيد قد تقــــود إلى حدوث انهيار و إر هاق نفسي وجسدي لدى العاملين ونتيجة لذلك تتولد الأفكار الــسلبية

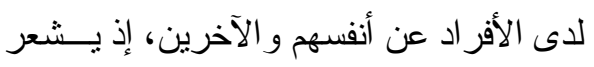
أغلبيتهم بضعف امتلاكهم القدرة على حـل الاصل مشاكلهم، وينتابهم شعورًا بالفشل و انخفاض

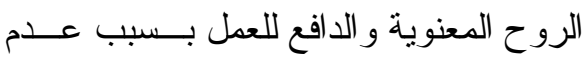


مجموعة القيم: التمكين وتــــاول المعرفــة، و عملية تعلم مستمرة، و هدف و احد، مكافــأة

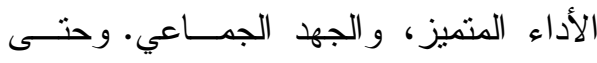

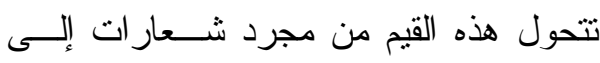
أفعال قوية ومؤثرة، وأساس منين للتعاملات

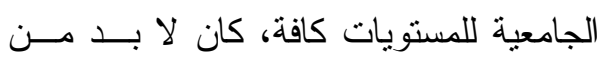

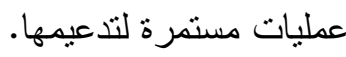

ففي مجال الموارد البشرية اعتمــدت الجامعة مجموعة من السياسات الحاكمة التي

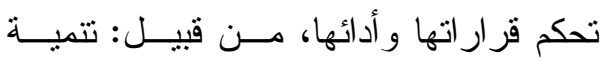
المو ارد البشرية للجامعة، التدريب المسستمر

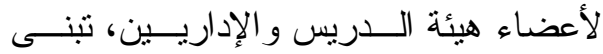
معايير و أساليب لتحفيز العــاملين وتحـسين الأداء. وفي مجال سياسات توافر المعلومات

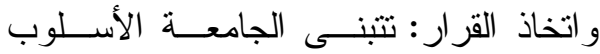
الديمقر اطي وسياسة الباب المفتوح في قيــادة الجامعة، إتاحة المعلومات الكافيــة و الدقية لـــة و المحدثة لمتخذي القرار، الالتــز ام بتطبيــق

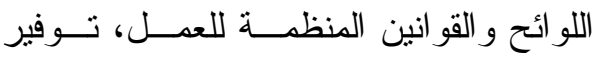

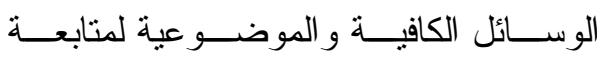

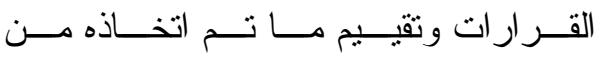

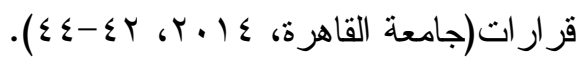
وتو اجه جامعة القاهرة طبقًا لدر استها

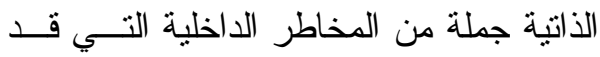
تعوق قدرتها على تتفيذ رؤيتهــا ورســالتها وخطتها التنفيذية، منل: وجود قوى معارضة للنطوير ولتطبيق نظم الجودة، ضعف تو افر
يدفعهم إلى ترك العمل و الهروب أو البقـاء و التحدث حول ظروف العمل كمحاولة لتغيير

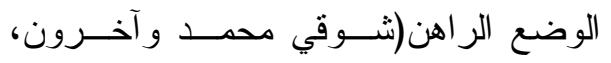
.$(1 \leq r, r \cdot 1 V$ كما ارتبط التهكم التنظيهـي بـسوء

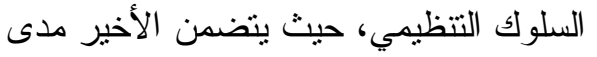
و اسعًا من السلوك الذي يضع قيودًا متعـددة

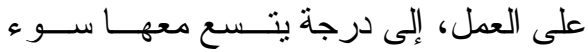
السلوك التنظيمي إلى الحد الذي يــصل إلــى

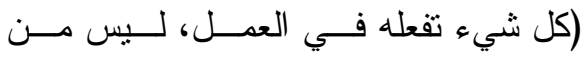

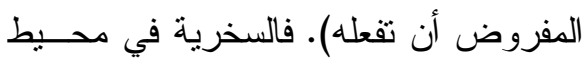

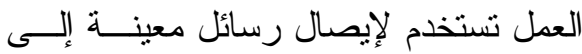

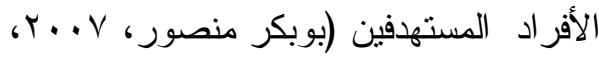

ولسنوات عديدة تز ايد قلــن مــديري المؤسسات وصانعي السياسات و البــاحثني،

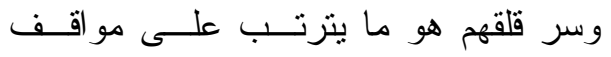

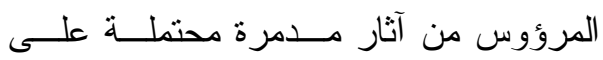
المؤسسات، وخاصة مو اقف التهكم التنظيمي.

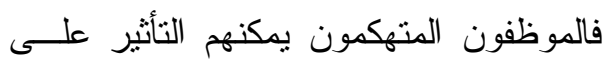

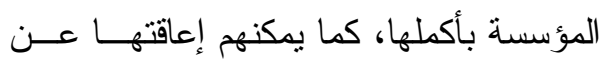
تحقيق أهــافها( Nagah Abd El-Fattah .(\& et al,2016,85 وتتطلق جامعة القاهرة فــي تحقيـق ريادتها من خلال تنبى مجموعة مــن القـيم

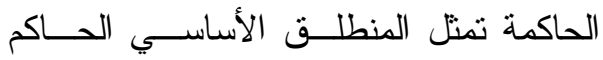

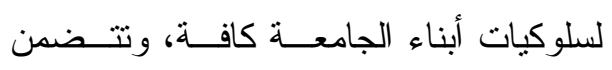


من البحث و الدراسة خاصة في البيئــة

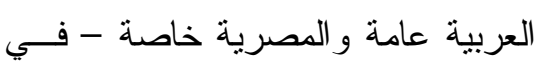
حدود علم الباحث- وذذلك على الــرغم من أهيته وتأثنيره الو اضح علـــى الأداء المؤسسي. - قد تفيد نتائج الدر اسة و اضعي السياسات ومتخذي القرارت بجامعة القاهرة لتعرف

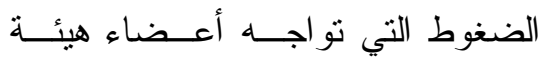

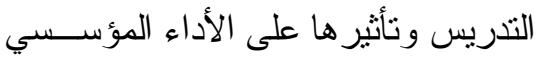
لايهم. - قد تساعد نتائج الدراسة متخذي القــرار بجامعة القاهرة في توفير المناخ الصحي

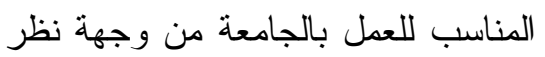
الأعضاء.

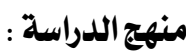
توظــف الدر اســـة الحاليــة المــنـهج الوصفي؛ نظرًا لتو افقه مع طبيعة الدراســـة

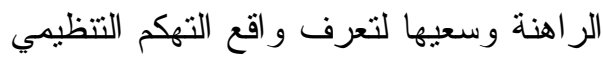
بجامعة القاهرة من وجهة نظر أعضاء هيئة

$$
\text { التدريس. }
$$

أداة الدراسة : - ماسن

تعتمد الدراسة على الاســنبانة كــأداة

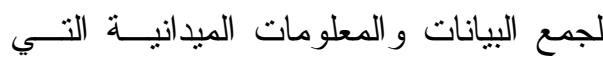
تساعد في تحقيق أهدافها.

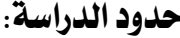
تقتصر نتائج الدر سأة، وقابليتها للتعميم فـي

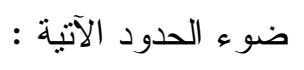

رأس مال بشري كفء لتتفيذ أهداف الخطة، قلة ممارسة سلطات الإدارة الرشيدة و الحاجة للمزيد من الإفصاح و الثفافية لتحقيق حوكمة

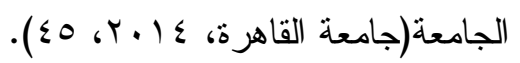
وفي ضوء ما سبق يمكن التعبير عن

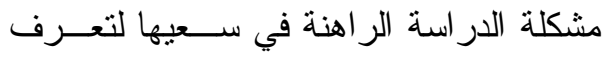
و اقع التهكم التتظيمي بــين أعــضاء هيئــة

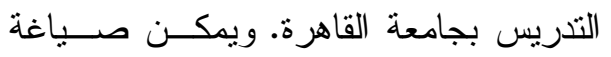
المشكلة في السؤال الرئيس الآتي : كيف يمكن التقليـلـل مــن ظــاهرة الــتهكم التظيمي بين أعضاء هيئة التدريس بجامعة القاهرة ؟

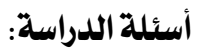
في ضوء ماسبق تهـف الار اســة للإجابــة عن الأسئلة الآتية: 1- ما التهكم التنظيمي، وأبعاده؟

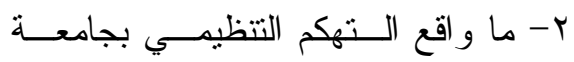
القاهرة من وجهة نظر أعضاء هيئـــة التدريس ؟ r- ما أهم التوصيات و المقترحات لتقليل التهكم التنظيمي في جامعة القاهرة ؟

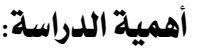

تستمد الاراسة الراهنة أهميتها من خــلال النقاط التالية : - تتناول الدراسة في شقها النظري متغير التهكم التتظيمي و الذي لم يأخذ نـــئيه 


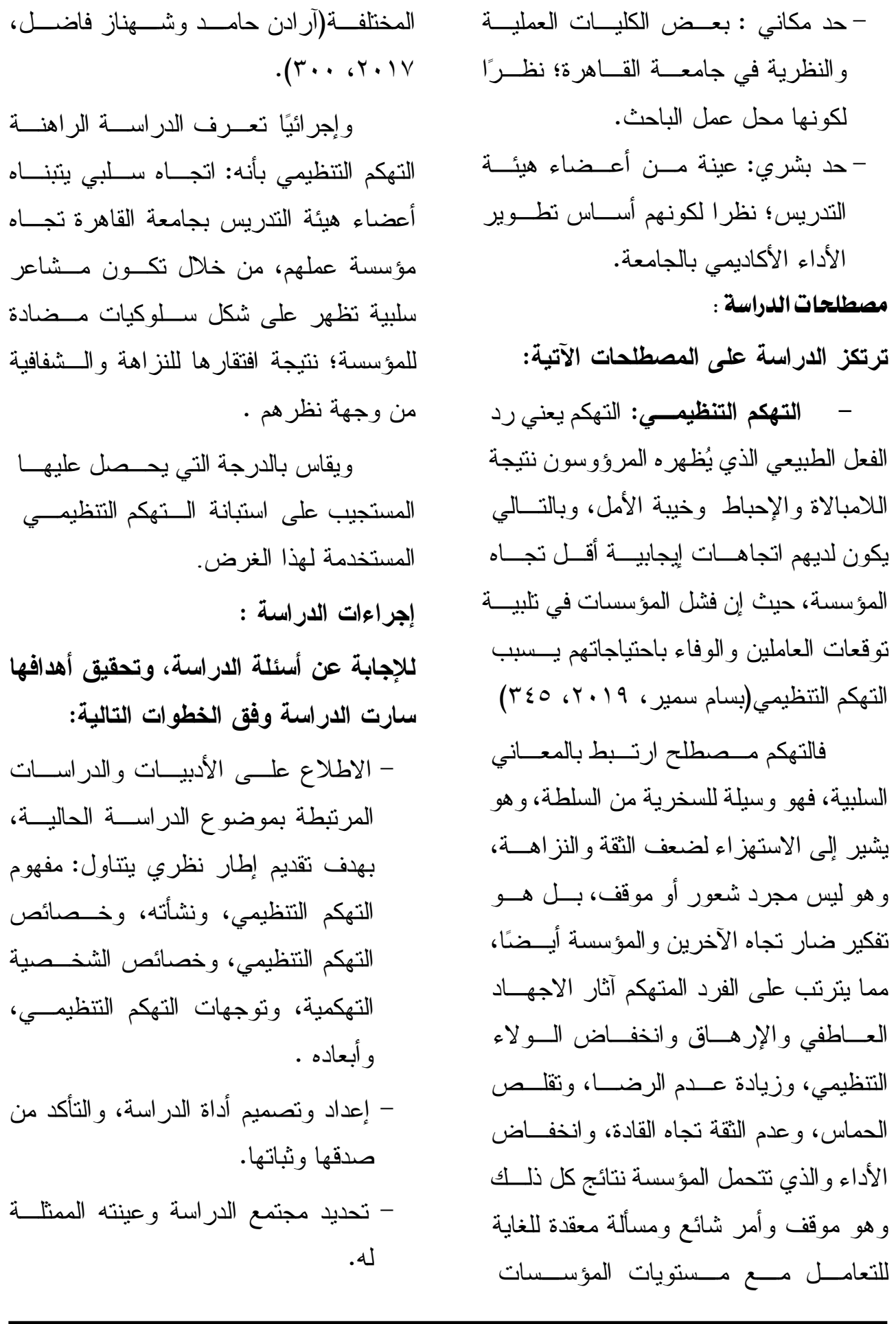


على درجات عالية على هذا المقياس يـرون

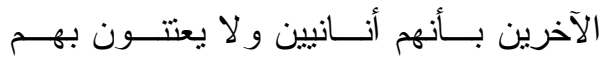

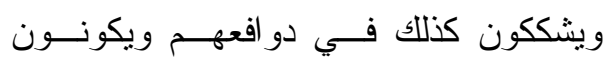
متحفظين و لا ينقون بعلاقات الآخرين . و المدخل الثاني يعرف الــتهكم بأنـــه بمثابة موقف متبلور لدى الفرد متجه نحـــ شيء ما. وقد ترجم الباحثون فكــرة الــتـكم كموقف في أربعة اتجاهــات بحثيــة، الأول

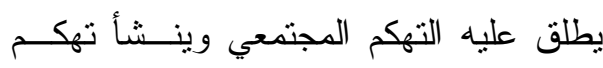
العاملين وفق هذا الاتجاه نتيجـــة التـأرجح و التقلب في البيئة السياسية و الاجتماعية لعمل المنظمـات أو بـسببب اســتغلال العـاملين وخاصة مع بداية الثورة الصناعية وكــللك بسبب فنثل وعود المنظمات المعاصرة فـي وخي تحسين جودة حبــاة العـــل، أى أن تطــــور

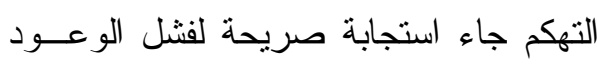

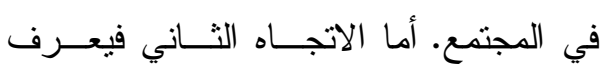
بالتهكم المهني الذي يقتصر فيه التهكم علــى

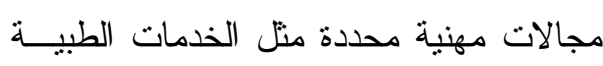

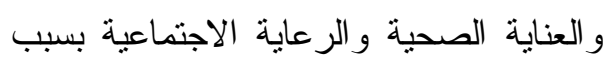

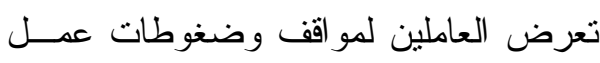
مختلفة لتوقعاتهم المبنية بخــصوص مثاليــــة فئس

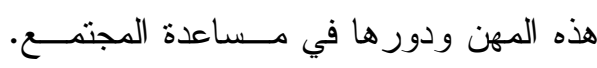
والاتجاه الثالث يطلق عليه التهكم نحو التغيير التتظيمي و الذي يقترح بأن جهود التغيير هي لئه

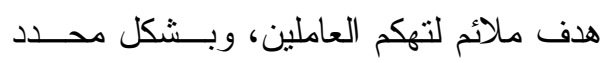

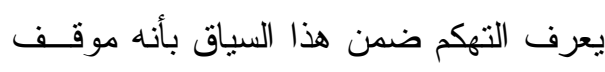

- تطبيق أداة الدراسة على عينة الدراسة. - رصد النتــائج ومعالجتهـــا إحــصائيًا، و الإجابة عن تساؤلات الدر اسة. - تقديم بعض التوصــيات و المقترحسات لتقليل ظاهرة التهكم التتظيمي بجامعــة القاهرة.

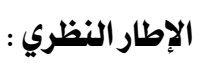
تتتاول الدراسة الحالية هنا أهم النقاط

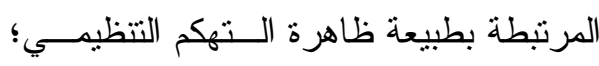

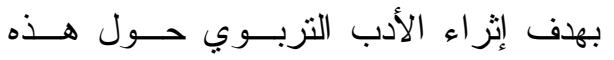
الظاهرة - قليلة المعالجـــة فـــي الأدبيــات

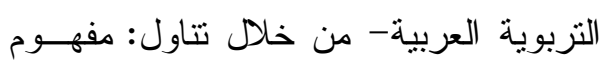
التهم التظظيمي، ونشأته، وخصائص التهكم

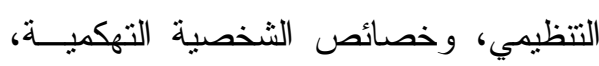
وتوجهات التهكم التتظيمي، وأبعاده. 囚 مفهوم التهكم التنظيمي: تتطلق تعريفات التهكم التتظيمي مـن مدخلين أساسيين: الأول، يعرف التهكم بأنسـه بمثابة ميزة شخصية ويناقش هــذا المــدخل

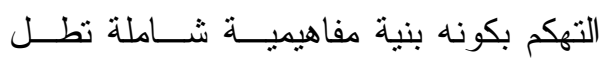
وتشرف بـشكل أساسـي علــى الطبيعــة

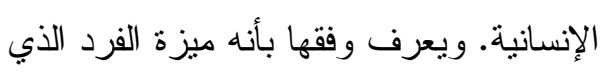

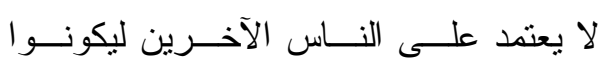

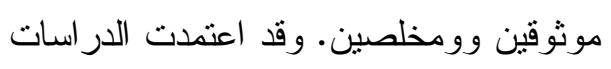

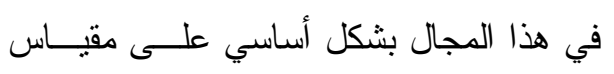

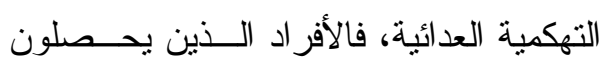


العثور على الخطأ عن طريــق الاحتقــار".

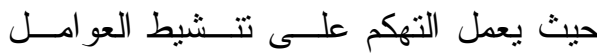
العاطفية مثل الغضب والازدر اء و الــضيق. باختصار تكوين مشاعر سلبية قوية. فالتهكم

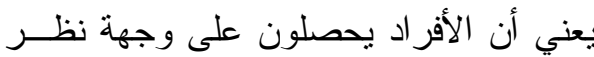
يائسة وحرجة نتيجة للتجـارب و المـشـاعر

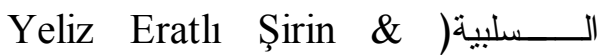
.(etal,2018,2010 وتمثل سلوكيات العمل السلبية سلوكًا معاديًا يهدف إلى إيذاء المنظمة وموظفيهــا.

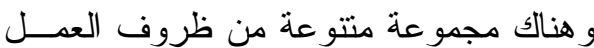
و الظروف التنظيمية(القيود المفروضة فــي الأداء، و الاجهاد الوظيفي، و الظلم، أو انتهاك العقد النفسي)، و التي تزيد من ردود الفعــل العاطفية و المشاعر السلبية و التي سوف تميل إلى احتمال زيادة سلوكيات العمــل الــسلبية،

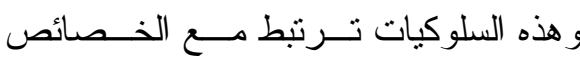
الشخصية من سمة الغضب و القلق، موضـــع

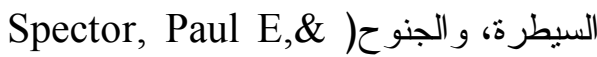
.(Fox, Suzy,2002,269

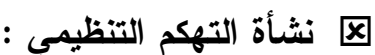
عند التحدث عن موضــوع الــتهكم بوجه عام يجب أن نعى أننا نتحـدث عـن مدرسة فكرية وفلسفة حياة كانت متأصلة في التاريخ الأغريقي القديم. ذلك التاريخ الـــي تز عرع في بيئته فلاسفة عدة ممن يحملــــون

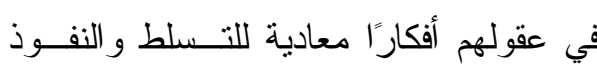

يتعلق بعملية التغيير و عدم جدو اه مــصحوبًا بمشاعر سلبية تجاه الأثخاص الذين يسعون نحو تحقيق أهدافه أو موقف ينسم بالتـشاؤم

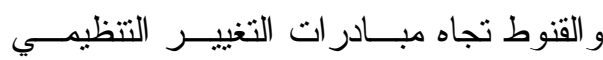

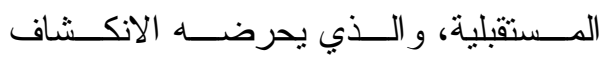
المتكــرر لـسوء إدارة محـــاو لات التغييــر

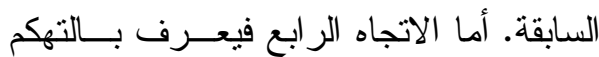

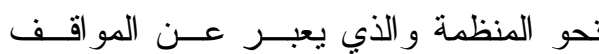

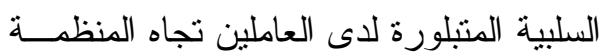

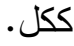

ويعد هذا الاتجاه أحسـث اتجاهــات تعريف التهكم التنظيمي من خــلال النظـــر للتنكم بأنه موقف سلبي تجاه المنظمة يتألف من فئ من ثلاثه عناصر هي: الاعتقاد بأن المنظمة تفتقد للاستقامة و النزاهة، وعو اطف سـلبية تجاه المنظمة، و الميل نحو سلوك الاستخفاف و الانتقاد تجاه المنظمة و الذي يتماشي مع هذه الاعتقادات و العو اطف ـ فهو مو اقف مرتبطة بالمنظمة تتـــف بالمعتقـدات و المــثاعر السلبية و السلوكيات المرتبطة وهـي تثثـلـل استجابة لممارسة اجتماعية أو شخصية ذات أمد تاريخي ويمكن أن تتغير بفعل الثأثيرات

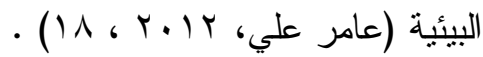

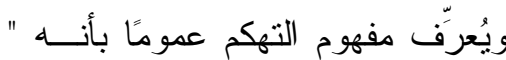
عدم الإيمان بالصدق و الصداحية في الدوافع

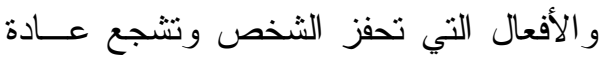
على التأكيد على ذلك بابنسامة، و الميل إلـى لـى 
أما فكرة التهكم فــي أدبيــات الإدارة و المنظمة فقد بدأت في نهايــة الثمانينيـات التهات

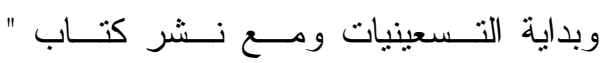

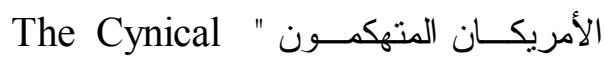
Americans، وقد كثف هذا الكتاب عـن الأسباب التي جعلت التهكم يــصبح منتـشرًا بين العاملين الأمريكان في المنظمات، كمــا

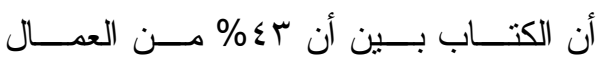

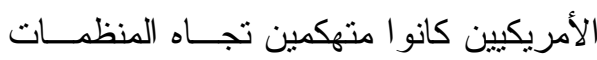

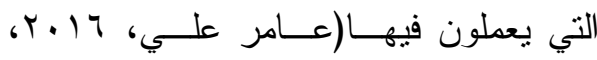
. (rᄉ. 凤 خصائص التهم التنظيمي : يمكن أن تتمثل خصائص التهكم التنظيمي من

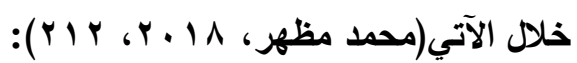
- يساعد التهكم المنظمة في جهود التغيير، إذ إن استكثاف حــالات الــتـكم تجـــاه التغييــر يمكـن المنظمــة مــن إيجــاد استر اتيجية تغيير ناجحة .

- ينظر للتهكم على أنه موقف وليس سمة.

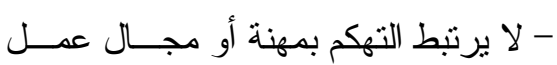

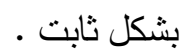
- يشمل التهكم : المعتقد، الثعور ، السلوك. - قد يكون قضية ثابتة أو لا يكون يؤخــذ

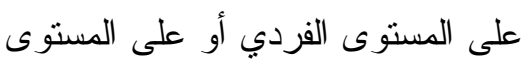

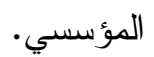

وحب الثزوة ومناصرة للتمـسك بــالأخلاق العالية و البساطة و الأدب. ويعتقد المتهكمون

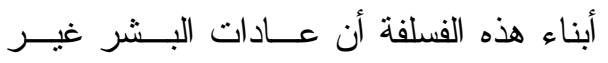

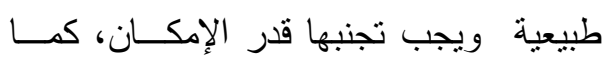

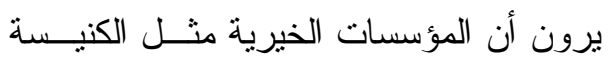
و الحكومة غير ضرورية وغير مجدية؛ لللك كانو ا يجهرون علنًا باحتقار هم لهؤلاء الأفر اد وعيل

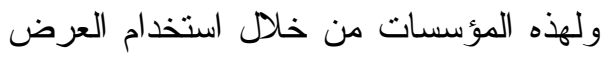

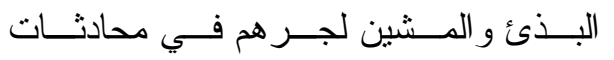
ومناقثات حتى يعبروا عن آرائهم ووجهات

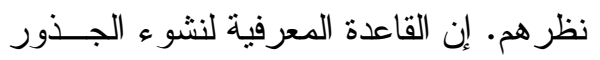

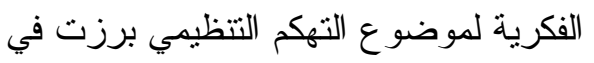

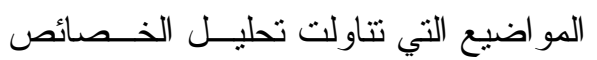
الشخصية للعاملين في الأربعينيات من القرن الماضي من خلال جامعة مينسونا في صياغة

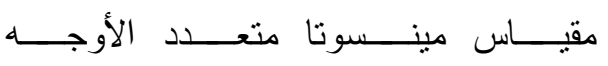

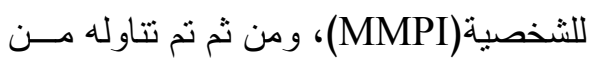
قبل كلا مــن كــوك وميــلي \& Cook Medley الثخصية العدوانية في بيئة العمل ـ وبهـــا

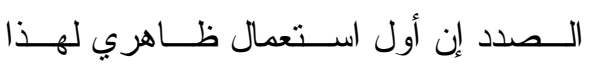
المصطلح في البيئة التنظيمية برز من خلال

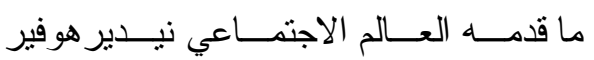

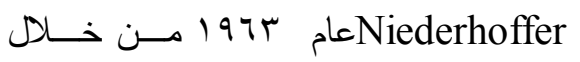

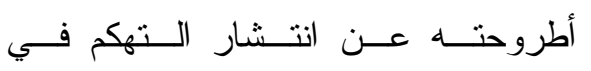
العمل(Delken, M,2004,12). 


$$
\begin{aligned}
& \text { فرص التزقيـة وزيــادة الابتكــار (هـادي }
\end{aligned}
$$

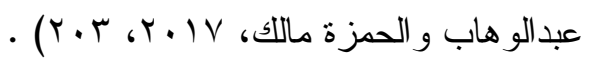

$$
\begin{aligned}
& \text { 囚 خصائص الثخصية التهكية : }
\end{aligned}
$$

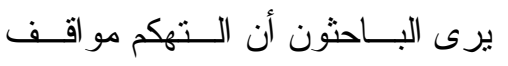

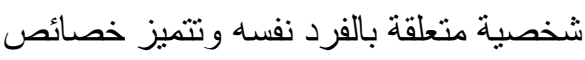

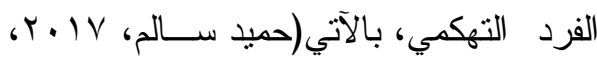

$$
\begin{aligned}
& :(17 \mathrm{~V} \\
& \text { - النظر إلى الآخرين على أنهـم أنـانيين } \\
& \text { وكذابين و غير مبالين. } \\
& \text { - التشكيك في دو افع الآخرين. } \\
& \text { - الحذر وعدم الثعور بالثقة في طبيعـة } \\
& \text { العلاقات الإنسانية. } \\
& \text { - عدائيين وقمعيين. } \\
& \text { - يمتعضون من مطالب الآخرين. } \\
& \text { - غير ودودين و لا يقــدمون المــساعدة } \\
& \text { لآخرين. } \\
& \text { 囚 توجهات التهم التظيمي : } \\
& \text { تتمحور توجهات الـتنهم التتظيهـي } \\
& \text { و أساليب علاجه في خمسة محسـاور رئبـسة }
\end{aligned}
$$

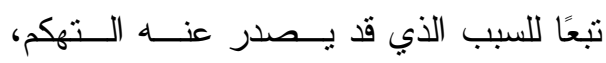

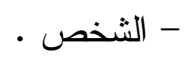

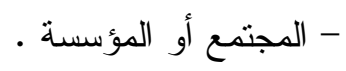

$$
\begin{aligned}
& \text { - المهنة. }
\end{aligned}
$$


وبخصوص التوجه الثالـــث فينــاقش

طبيعة المهن التي قد تكون في حـــد ذاتهــا مصدرًا للتهكم، أي أن التهكم هنا يكون نتيجة

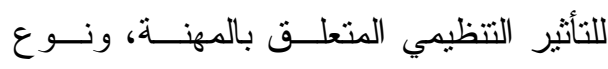
الخدمة المقدمة و القوانين التي تحكمها. حيث تشير نتائج الدراسات إلى أن التهكم المهنـي يكون أكثر كثافة فــي الوظـــائف العاديـــة،

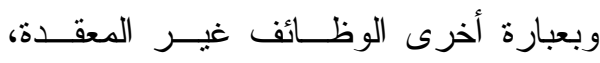
و الوظائف القائمة على التكـــرار ، الوظـــائف التي يتم فيها تقييد حق العاملين في التـدخل من حيث معالجة الأخطاء. كما توجد بعض

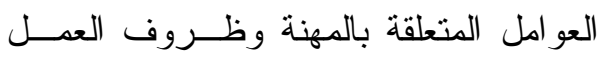
و التي تؤثر على انتشار التهمم التتظيمي من عدمه، منّل: جودة العمل وتعقيده ومـستوى المشاركة في عمليات صنع القرار المتعلقــة بهذه المهنة، وضــــف المنـــاخ التتظيمـــي، و القلق من الفصل، و ارتفاع مستوى ضــــف الأمن الوظيفي، و التكليف بمهام غير عادلــة و الفشل في تطبيق المعايير الأخلاقية داخـل

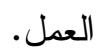

ويتتاول التوجه الرابع التهم الصادر

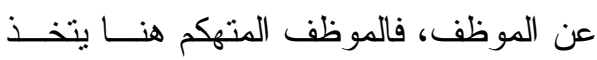
التهكم وسبلة للتعبير عن الإحباط و البــأس،

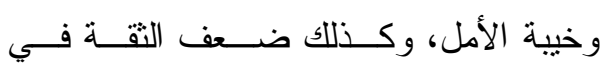
المؤسسة التي يعمل بها، وتجـــــاه المــديرين التتفيذيين وأثنياء أخرى تتعلق كلها بـسياق
- الموظف -

- التغيير التنظيمي -

ففي المحور الأول الخــاص بــالتهكم

الصـادر عـن الــشخص أو الفــرد تـشثير

الدراسات إلى كون التهكم مرتبط بالطبيعـة

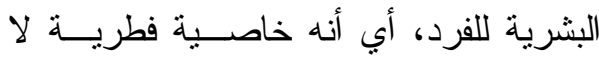

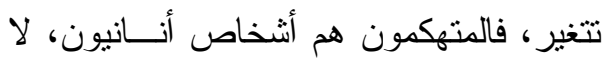

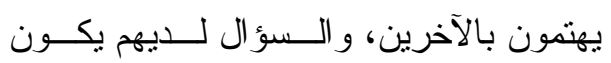
الغرض منه التشكيك بالآخرين. وفي العموم

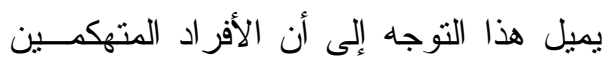

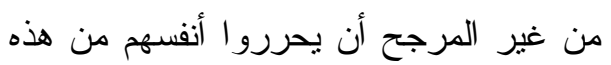
الخصائص؛ كون التهكم نتيجة بنية شخصية

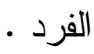

أما التوجه الثاني المتعلق بالمجتمع أو المؤسسة المصدرة للتهكم فيركز على التهكم الاجتماعي المؤسسي، أي أن مواطني الدولة

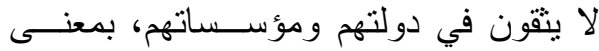

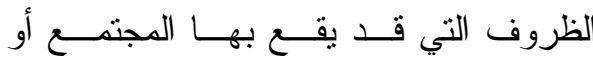
المؤسسة وتؤدي لعملية التهكم. فمــع بدايــة

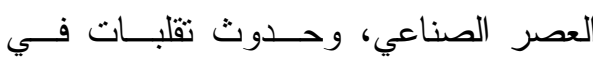

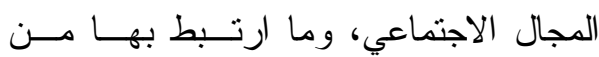
مشكلات أثزت بالسلب على نوقعات الأفر اد. وكم الإحباطات التي عانت منها مسستويات مختلفة من العلاقات في المجال الاجتمــاعي الاعي كل ذلك يلعب دورًا كبيرًا في ظهور النتاؤم

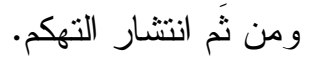


و الإخلاص و الدو افع الإنسانية. ولهذا الاعتقاد

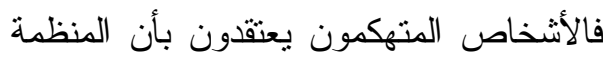
تخوفهم أو تتأمر عليهم بسبب نقص المبادئ

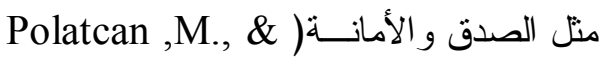
(Titrek,O.,2013,1293 ) البعد الوجداني

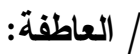

يتضمن ردود الأفعال العاطفية القوية

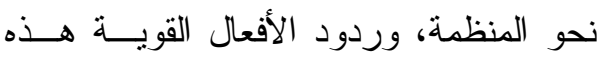

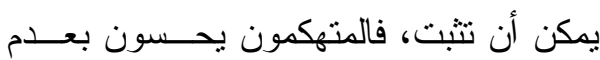
الاحتر ام و الغضب تجاه منظماتهم و الكر اهية لهن و الإزعاج عندما يفكرون بمنظماتهم. فهو بعد ولدمان

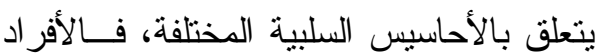
ذوو المستوى التهكمي العـالي سيـشعرون

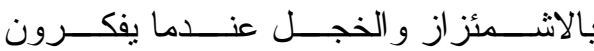

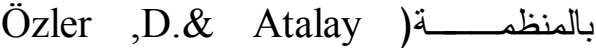
•(,C.,2011,28 - - البعد السلوكي : إن وجود الأفعال التي تكون ظـــاهرة للآخرين أو مخفية عنهم و التي تتصف بنوع من العدائية و عدم الإيمان بالمدر اءو عدم الثقة بالأفر اد أو المجموعات أو العقائد المؤسسية تشكل البعد لثالث للتهكم التنظيمــي، و التــي تكون دو افعها الحط من قيمة وقدر المنظمــة،

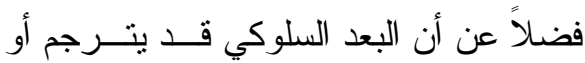
يظهر أيضًا من خلال النقد الحاد، والــتكهن بأحداث متشائمة و التعبير الساخر و الـسلوك غير اللفظي مثل النظر بشكل مقيت، والابتسام
و أخيرًا التوجـهـ الخــامس المتعلــق بالتهكم الصادر عن التغيير التتظيمي، فالتهكم هنا مرده وجود وجهة نظر سلبية تؤكــد أن

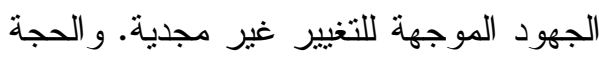
الأكثر أهمية في التغيير التنظيمسي هـــي أن الجهود الفردية لحل المشاكل ليست كافيــة،

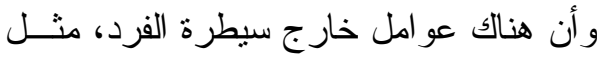

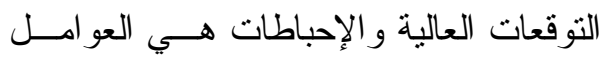
الرئيسة المسـبية للــنهم التنظيهـي فــي Yeliz Eratlı Şirin \& (المؤســسـات .(etal,2018,2010 囚 أبعاد التهكم التنظيمي : أثنار الباحثون إلى وجود ثلاثة أبعـاد للتهكم التنظيمي يمكن تحديدها في: الاعتقاد، و العاطفة، و السلوك. حيث تعتبر هذه الأبعاد بمثابة مكونات التهكم التتظيمي، التـي مــن خلالها يمكن التفريق بــين مفهـــوم الــتهكم ومفاهيم تتظيمية أخرى منل الثقة التتظيميــة و الالتز ام و الرضا الوظيفي(ميثــاق هـاتف،

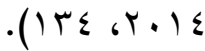
- - البعد المعرفي/ الاعتقاد :

ويقصد به اعتقاد الأفر اد أن المنظمــة

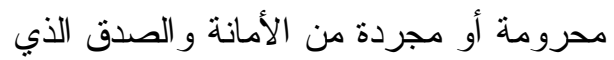
يرتب بالــشعور الـسلبي مثـلـل الغــضب و الاحتقار و الإدانة و الاستتار ـ فسلوك التهكم هنا يعني الميل نحو ضعف الإيمان بالطيبــة 
بكليات نظرية وكليات عملية، وكليات داخل الحرم الجامعي، وأخرى خارجـــ- كليــات

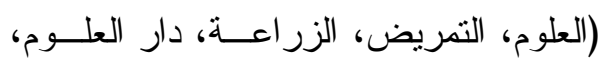

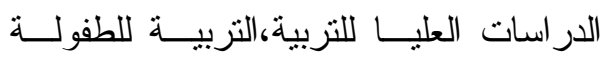
المبكرة)-؛ كعينة ممثلة لمجتمــع الدر اســـة.

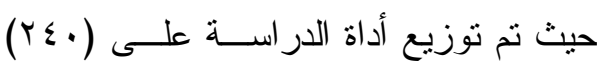

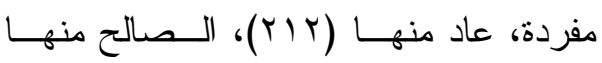

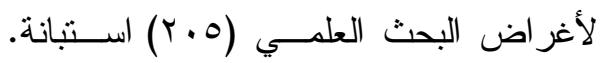
و الجدول (1) يبين توزيع أفراد العينة حسب لاعب متغير ات الدر اسة (الجنس، طبيعة الدراســـة بالكلية، الوظيفة، سنوات الخبرة).

بتكلف وتقاسيم الوجه وتعابيره وحركة الرأس

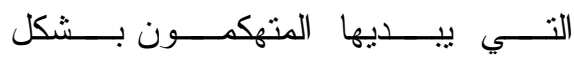
Kutanis R. O. \& متكـرر (C) • (Cetinel,E.,2010,188 إجراءات الدراسة الميدانية: مجتمع الار اسة وعينته: تمنل مجتمع

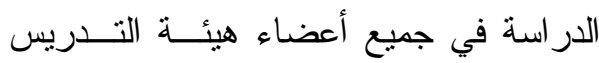

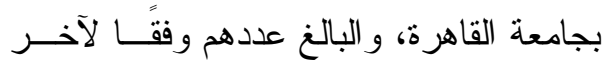

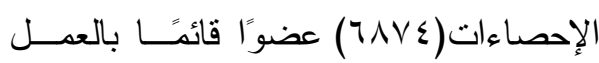

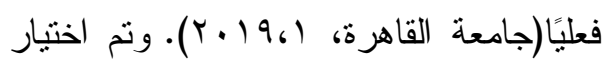
عينة الدراسة بالطريقة الطبقيــة العــشوائية

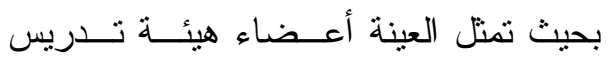

جدول(1)

توزيع أفراد العينة وفقًا لمتغير جات الاراسة (ن = ه ـ r)

\begin{tabular}{|c|c|c|c|c|}
\hline النسبة\%\% & العدد & \multicolumn{2}{|c|}{ متغير ات الدراسة } & م \\
\hline 00,1 & $11 \pi$ & ذكر & \multirow[t]{2}{*}{ الجنس } & 1 \\
\hline$\varepsilon \varepsilon, 9$ & 94 & أنثي & & \\
\hline $0 \vee, 7$ & 111 & نظرية & \multirow[t]{2}{*}{ طبيعة الدر اسة بالكلية } & \multirow[t]{2}{*}{ r } \\
\hline$\varepsilon Y, \varepsilon$ & AV & عملية & & \\
\hline ऍی & VA & مدرس & \multirow[t]{3}{*}{ الوظبفة } & \multirow[t]{3}{*}{$r$} \\
\hline 0. & $1 \cdot r$ & استاذ مساعد & & \\
\hline ir & ro & أستاذ أستاذ & & \\
\hline ro, $q$ & or & أقل من · ـ سنو ات & \multirow[t]{3}{*}{ سنو ات الخبرة } & \multirow[t]{3}{*}{$\varepsilon$} \\
\hline 00,1 & 111 & r من · إ إلى r & & \\
\hline 19 & rq & أكثر من • r & & \\
\hline $1 \ldots$ & r.o & \multicolumn{3}{|c|}{ الإجمالي } \\
\hline
\end{tabular}




$$
\begin{aligned}
& \text { r, }
\end{aligned}
$$

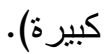

- صدق الأداة: للتحقق مـن صــــق أداة

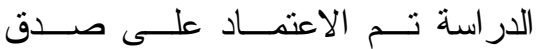
المحكمين، حيث عرضــت الاســنبانة

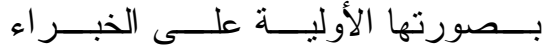

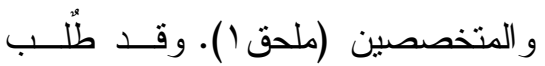
منهم إبداء الر أي حــول مــدى صــحة العبار ات، ومناسبتها لمعرفة واقع التهكم التنظيمي بجامعة القاهرة، مــع حريــة

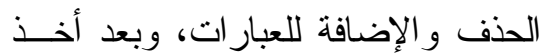
رأي المحكمــين وإجــر اء التعـــيلات، استقرت الاستبانة في صورتها النهائية. حيث شملت (10) عبارة، تم تقـسيمها لثلاثة محساور ، هـي: أبعــاد الـتنهم التتظيمي(9 (1)، أسباب التهكم التتظيمسي لتي (ع () عبارة، آليات الحد مسـن الــتهكم التنظيمي(1) ( ) عبارة (ملحق r) r).

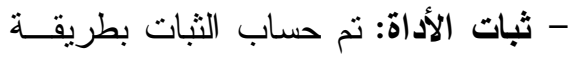
إعادة الاختبار (Test- Re -test)، إذ تم توزيع الاستبانة على عينة مبدئية من أعضاء هيئة التدريس، بلغ عددهم (Tr)

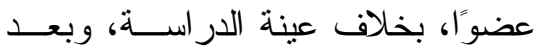
مضى أسبو عين نم إعادة تطبيــق الأداة على نفس العينة، وبعد ذلك تم حسساب

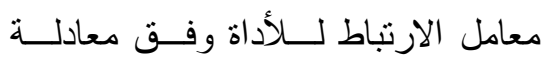
بيرسون التتبؤية، وبلغ معامـل ثبـــات
ومن الجدول (1) يتضح وجود غلبــة فيما يتعلق بتمثيل فئة الذكور عن فئة الإناث في متغير الجنس، وفئة الدراسة النظرية في متغير طبيعة الدراسة، وفـي فئــة الأســناذ

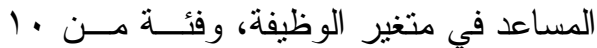
إلى ·r سنة في متغير سنوات الخبرة، ويدل كل ما سبق على صدق تمثيل العينة لمجتمع

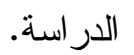
- أداة الاراسة: قام الباحث ببناء وتطوير

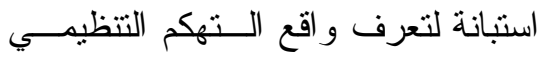
بجامعة القاهرة من وجهة نظر أعــضاء

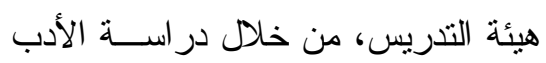
التزبوي و الدر اسات السابقة، وكل ما له له صــلة بمتغيـــرات الدر اســـة الر اهنـــة.

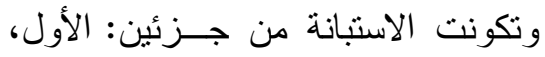

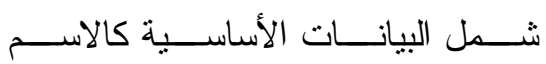
(اختياري)، الجنس، طبيعــة الدراســـة

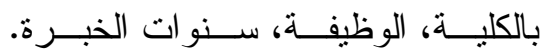
و الثاني، شمل عبارات الاستبانة التي تم توجيهها لعينة الدراسة حول و اقع التهكم التتظيمي بكلياتهم، وأمام كل عبارة ثلاثة

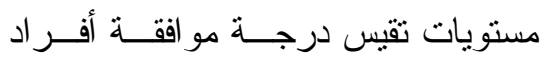

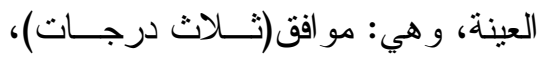

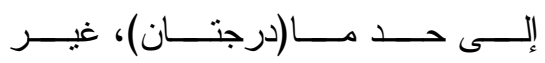
موافق(درجة). وتــمـ اعتمــاد القاعـــدة

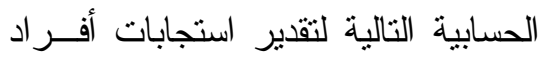

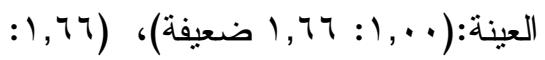


الأداة ككل (V9.)، وهو معامل ثبـات البيانات إحصائيًا، حيث يتم هنا تعرف و اقع

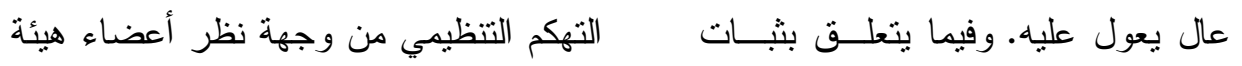

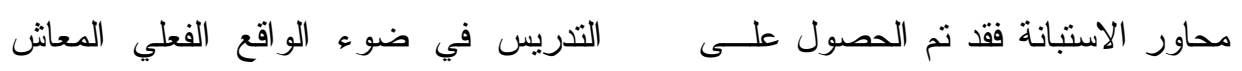
المعاملات التالية: المحور الأول: معامل بكلياتهم، وذلك من خلادل نرتيب محاور أداة

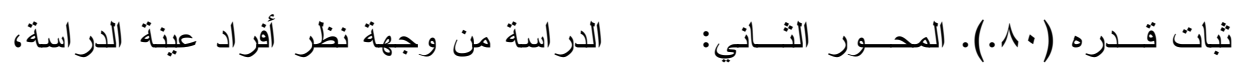

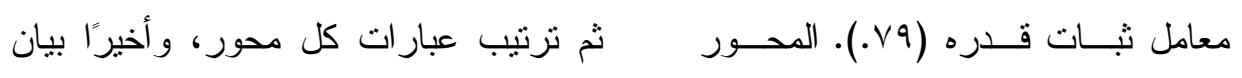

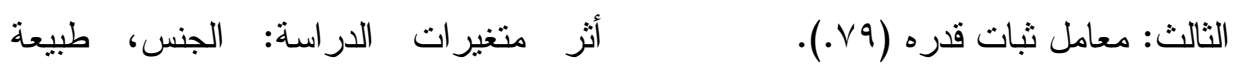

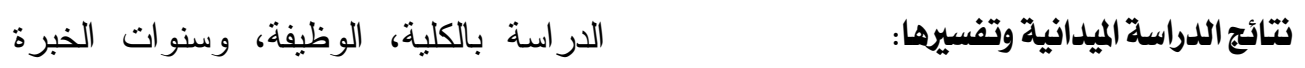

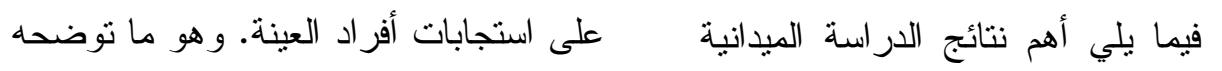
وذلك بعد تطبيق أداة الدراسة، ومعالجة الجداول التالية:

جدول (r)

ترتيب محاور أداة الدراسة من وجهة نظر أفراد عينة الدراسة

\begin{tabular}{|c|c|c|c|c|}
\hline الترتيب & المتوسط الحسابي & عدد عبارات المحور & المحاور & b \\
\hline 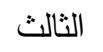 & $1, \lambda 1$ & 19 & أبعاد التهكم التتظيمي & 1 \\
\hline الثناني & $r, .0$ & $1 \varepsilon$ & أسباب التهكم التتظيمي & r \\
\hline الأول & $r, V \varepsilon$ & 11 & آليات الحد من التهكم التتظيمي & r \\
\hline
\end{tabular}

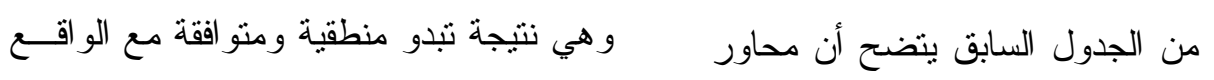

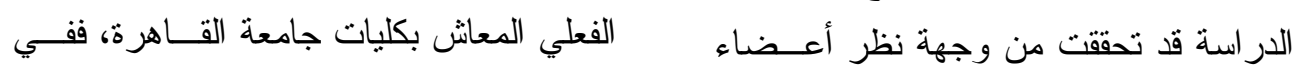

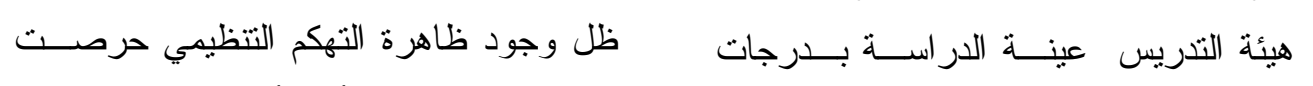

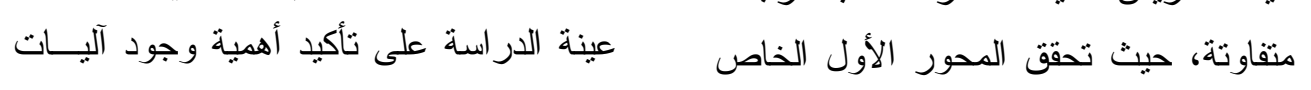

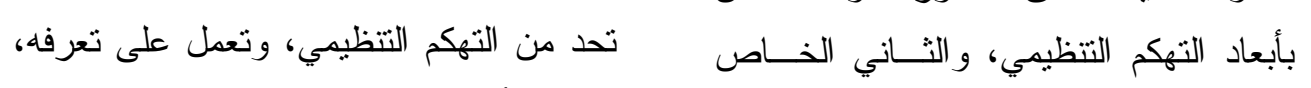

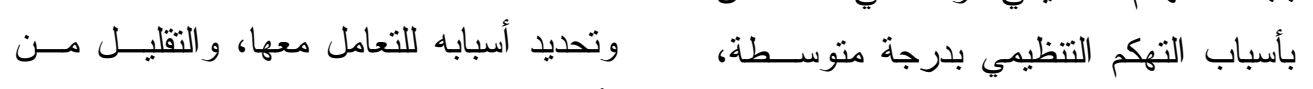

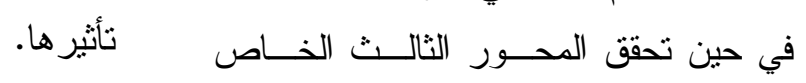
بآليات الحد من التهكم التنظيهـي بدرجــة

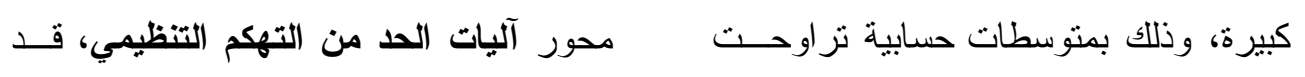

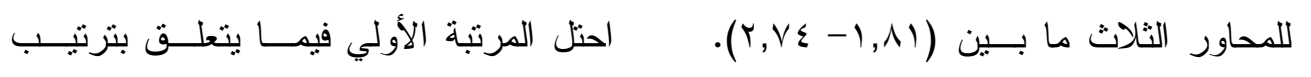


المناسبة للتعامل معها كمنهج إجر ائي يعدـلـ

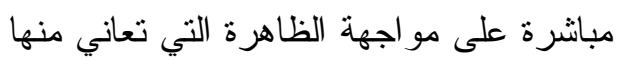
المؤسسة التعليمية.

وهي نتائج تتفق مع أثنارت إليه در اسة

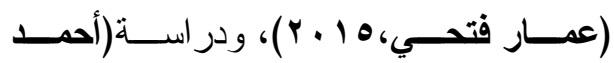
وآخرون Ahmed,W. \&et al,2013) من (ب) ،

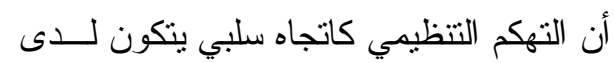

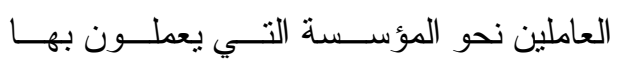

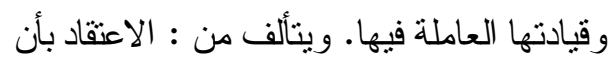

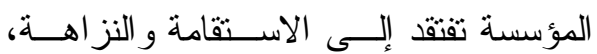
و عو اطف سلبية تجاهها، و الميل نحو ســلوك الــ

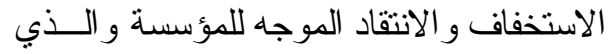

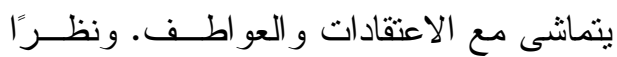
لارنباط التهكم التنظيمي بالسلوكيات المنحرفة في العمل، لذا ينبغي العمل على إيجاد الحلول

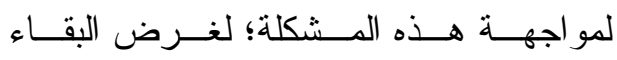

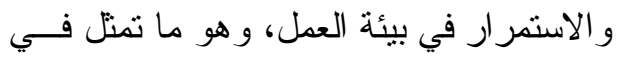
كون آليات الحد من التهكم التنظيمي جــاءت لهن

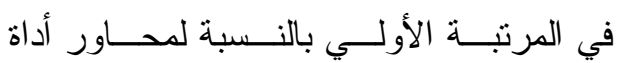
الدر اسة من وجهة نظر العينة. وفيما يتعلق بتزتيب عبار ات كل محور من محاور الأداة فالجداول التالية توضح ذلك.

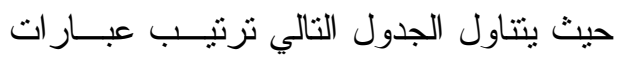

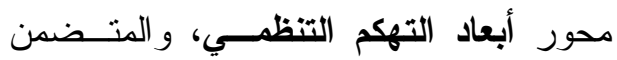

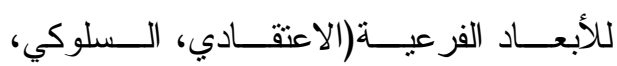
العاطفي) وذللك على النحو الآتي:
محاور أداة الدر اسة من وجهة نظر أفــر اد

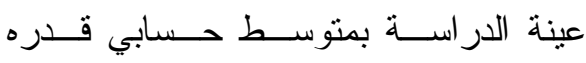

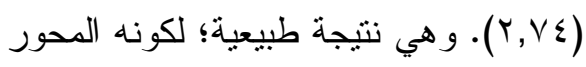

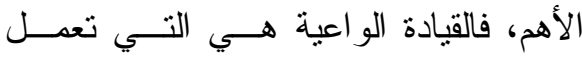

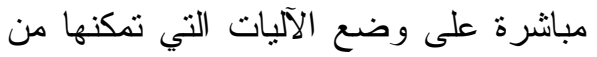

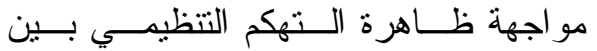

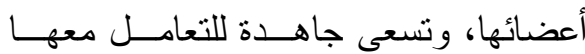
وتعرف مبرر اتها ومدى انتـشار ها؛ حتـى

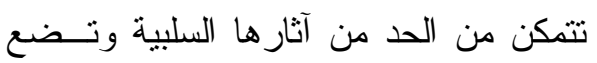
خطة القضاء عليها نهائيًا. في حين جاء محور أسباب الـتـهم التنظيمي في المرتبة الثانية بالنسبة لتزتيب محاور الدراسة من وجهة نظر أفراد العينة

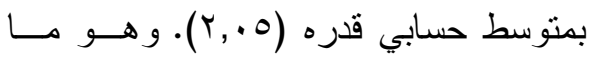

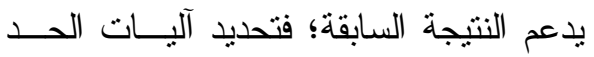

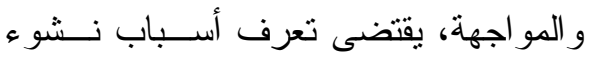
الظاهرة، وهو الأمر الذي يشير لوعي عينة

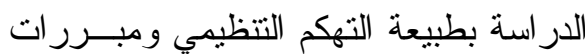

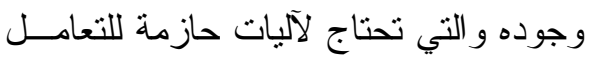
معها. وفي المرتبة الأخيرة جــاء محسـور أبعاد التهم التظيمي بمتوسط حسابي قدره ( (1, ()، وذلك من وجهة نظر العينة. وهو الأمر الذي يمكن تبريره بوعى أفراد العينة بأهمية التركيز مباثرة على تعرف أســبـاب

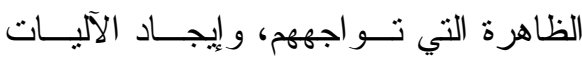


جدول(ז)

ترتيب عبارات محور أبعاد التهم التظمي (البعد الاعتقادي) من وجهة نظر عينة الدراسة

\begin{tabular}{|c|c|c|c|}
\hline 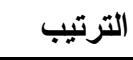 & المتوسط الحسابي & عبارات المحور & b \\
\hline 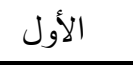 & 1,94 & إدارة كليتي تقول شيء وتفعل شيء آخر & 1 \\
\hline 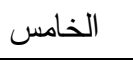 & l, Ar & إدارة كليتي لا تؤدي عملها بشكل مُرضِى & r \\
\hline 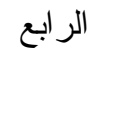 & 1,10 & حساب صالح العمل إدليتي أكثر اهمًاً بتحقيق مصالحها الخاصة على & r \\
\hline 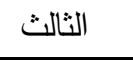 & $1, \wedge \vee$ & أهداف كليتي وممارساتها تفتقر للقو اسم المشتركة & $\varepsilon$ \\
\hline 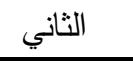 & $1, \wedge \wedge$ & إدارة كليتي لا تخبرني عن كل ما يتعلق بعملي داخل الكلية & 0 \\
\hline 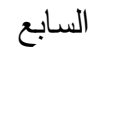 & $1, v \cdot$ & اعتقد أن ذلك لا بحلى إدارة كليتي أنها تتجه نحو أداء شيء معين، & 7 \\
\hline 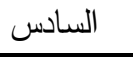 & $1, \sqrt{ } 7$ & المجتمع الخارجي لا يبدي احتر امًا و اضحًا لكليتي & $v$ \\
\hline
\end{tabular}

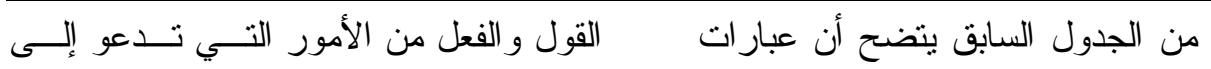

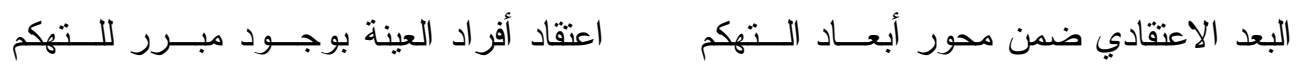

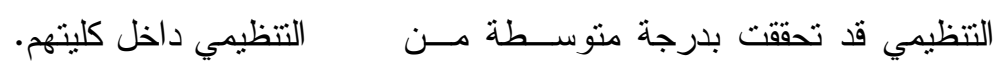

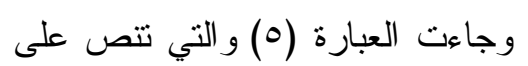

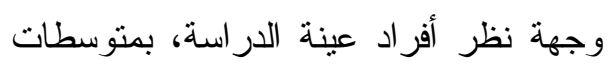

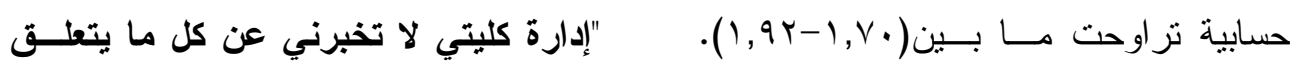

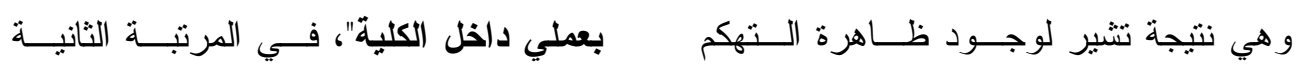

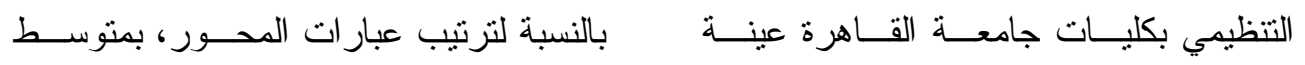

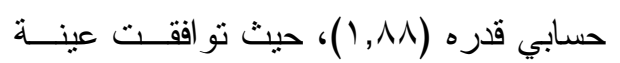
الدر اسة. الدراسة على جعل هذه الممارسة في المرتبة

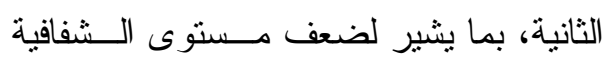
كما يتــضـح أن العبــارة (1) و والتهـي تتص على" إدارة كليتي تقول شيء وتفعـل لفيل

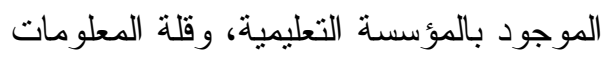

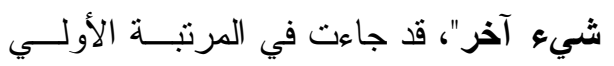

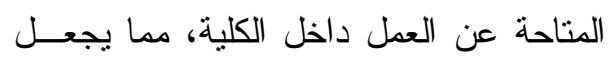

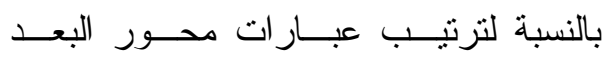
الاعتقادي، وذلك من وجهة نظر أفر اد عينة أفرادها في حالة تخبط وعزلة عــن محسل

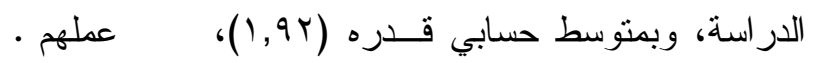

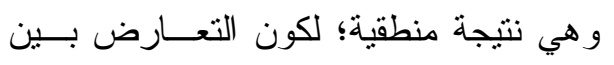




$$
\begin{aligned}
& \text { تعبر في أغلب الأحيان عن الإحباط و التشاؤم }
\end{aligned}
$$

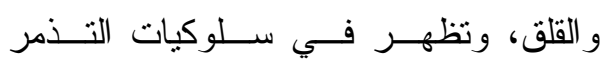

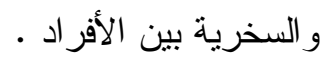

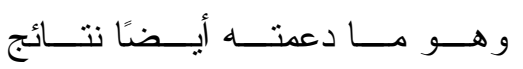

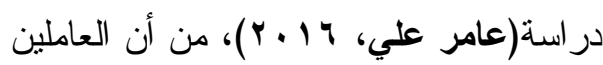

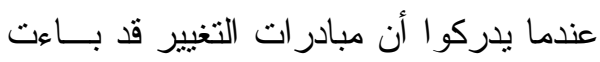

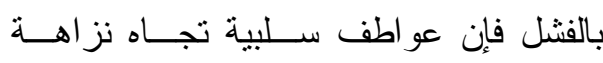

مؤسستهم ومصداقية عملها تكون قد تشكلت

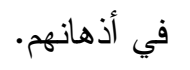

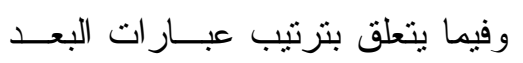

السلوكي ضمن محور أبعاد التهكم التتظيمي،

الجدول الآتي يبين ذلك:

وفي المرنبة الأخيرة جاءت العبـارة

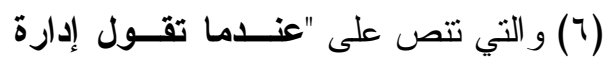
كليتي أنها تتجه نحو أداء شيء معين، اعتقا أن ذللك لا يحدث"، وذلك من وجهة نظر أفر اد

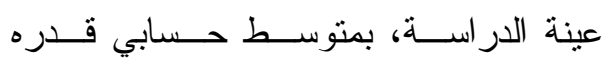

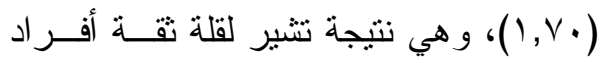

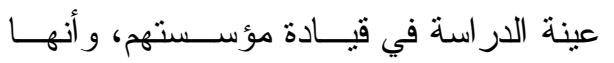
غالبًا لا تلتزم بما تقطعه من وعود.

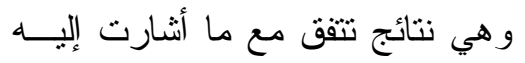

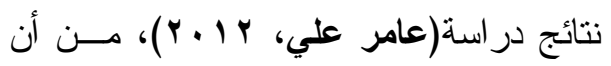

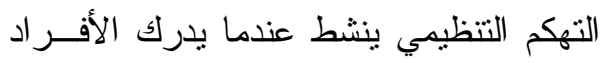

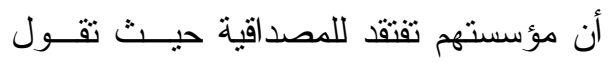
شيء وتفعل شيء آخر ، كما أن ممارسـاتها

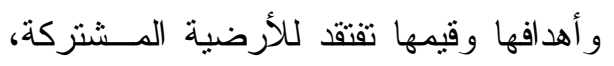
مما يسهم في توليد مشاعر عاطفيــة ســيئة جدول(ع)

\begin{tabular}{|c|c|c|c|}
\hline الترتيب & الحستوسطي & عبار ات المحور & b \\
\hline الأول & $r, \cdot V$ & اثنكو لأصدقائي خارج العمل عن الأشياء السيئة التي تحدث في كليتي & 1 \\
\hline الثاني & $1,9 \vee$ & اتبادل نظر ات الاستياء مع زملائي بالكلية & r \\
\hline 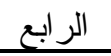 & $1,7$. & اسخر من الثعار ات التي تتبناها الكلية & r \\
\hline الخامس & $1, \varepsilon$. & اسخر من المبادر ات التي تتبناها الكلبة & $\varepsilon$ \\
\hline الثالث & $1,7 \mathrm{~V}$ & انتقد ممارسات وسياسات الكلية مع الآخرين داخل وخارج الكلية & 0 \\
\hline 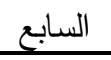 & $1, r Y$ & اقدم معلومات خطأ في بعض الأحيان عن كليتي & 7 \\
\hline 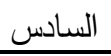 & 1, ro & أقلل من شأن ما يقوم به بعض الزملاء من إنجاز ات & $\checkmark$ \\
\hline
\end{tabular}

ترتيب عبارات محور أبعاد التهم التنظمي (البعد السلوكي) من وجهة نظر عينة الدراسة

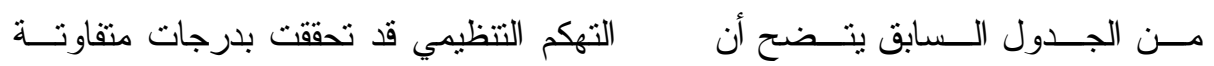

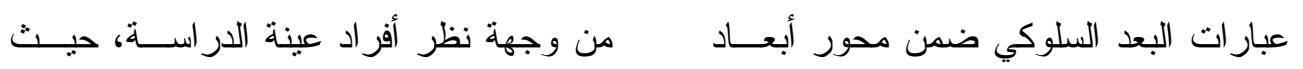


يشير للجوء أعضاء هيئة التذريس من عينــة الدراسة للأساليب و الوسائل الكلامية والرمزية لفية أولاً في تهكمه، ورغبتهم في إيصال رسائل ولئل

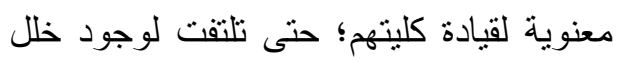

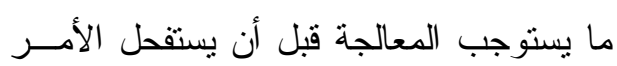
وتزداد الأضرار. وفي المرنبة الأخيرة جــاءت العبـارة

(T) و التي نتص على "(قام معلومات خطأ في

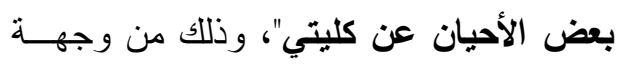

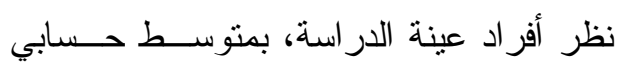

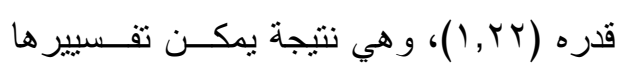

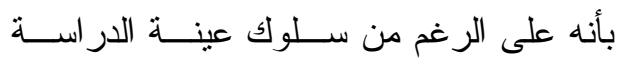

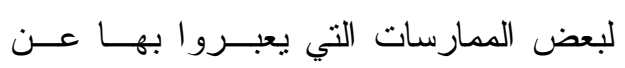

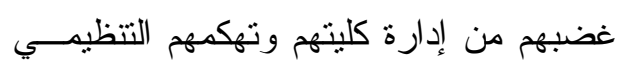

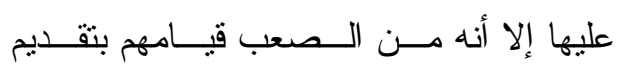
معلومات خطأ عن كليتهم تتفيسًا لمـشـاعر هم السلبية تجاها، كما أن من اليسير الآن تجميع

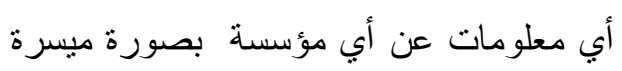
وسهلة .

وهي نتيجة تتفق مع ما أثنارت إليـــ

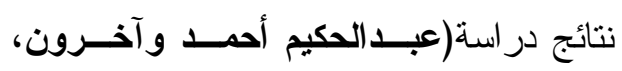

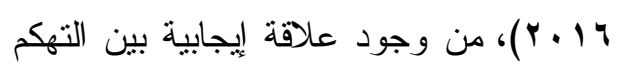

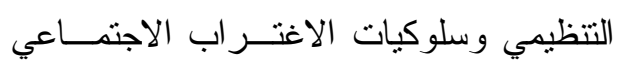

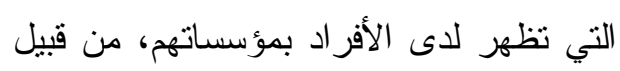
الثكوى من المؤسسة بالبيئة الخارجية.

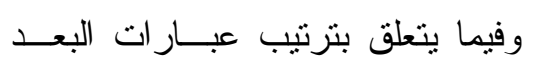
العاطفي ضمن محور أبعاد التهكم التتظيمي، الجدول الآتي يبين ذلك:

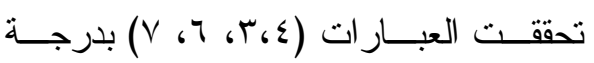

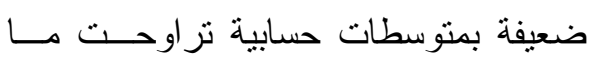

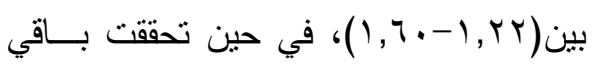

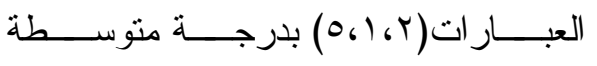

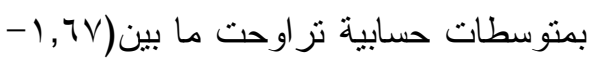

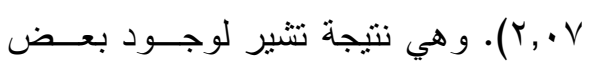
الممارسات السلوكية المعبرة عـنـ الــتهكم

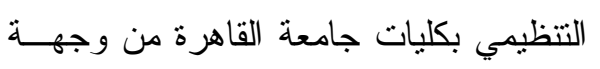
أعضاء هيئة التدريس عينة الدر اسة.

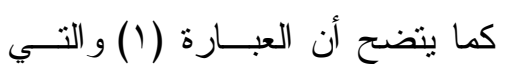

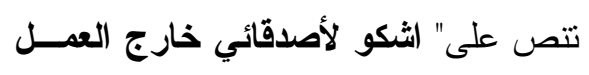

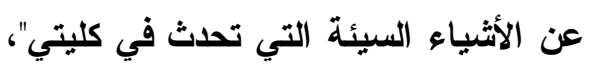

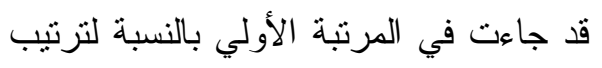

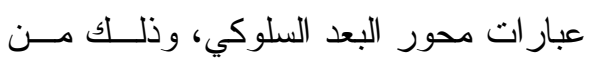

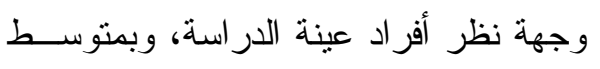

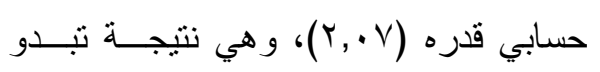

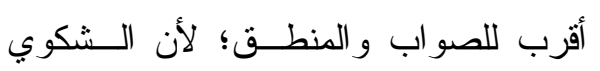

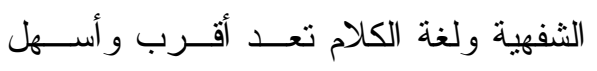
الوسائل المستخدمة من الإنسان للتنفيس عما ولفي يجيش في صدره، كما أنها أولي الوسـائل لونس لايه وفي حالة صعوبة استخدامها قد يلجـأ لوسائل أخرى تتجاوز مرحلة الكلام.

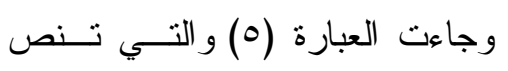
على " اتبادل نظرات الاستياء مع زملانـــي

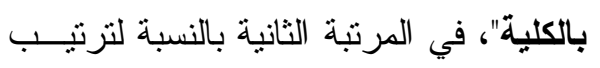

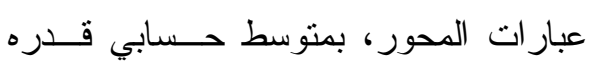

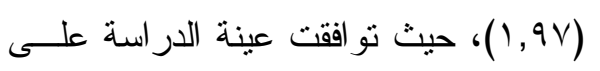

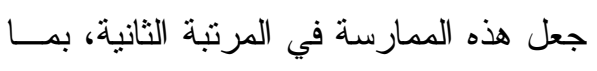




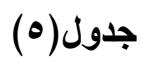

ترتيب عبارات محور أبعاد التهكم التنظمي (البعد العاطفي) من وجهة نظر عينة الدراسة

\begin{tabular}{|c|c|c|c|}
\hline الترتيب & الحسابي & عبار ات المحور & r \\
\hline الأول & $r, 19$ & أشعر بتفاوت بين أهدافي و أهداف كليني & \\
\hline الثالث & l,Ar & أثشعر بالرغبة في قضاء سنو ات حباتي المهنية في كلبني & r \\
\hline الثاني & $r, \cdot \Lambda$ & أُنعر بضعف انتمائي لكليتي & r \\
\hline 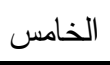 & $1, \sqrt{ } 7$ & أشعر بالأمان داخل كليتي & $\varepsilon$ \\
\hline الرابع & $1, \vee 9$ & أُثنعر بالاستياء عندما أخبر الآخرين أني أعمل في كلبتي & 。 \\
\hline
\end{tabular}

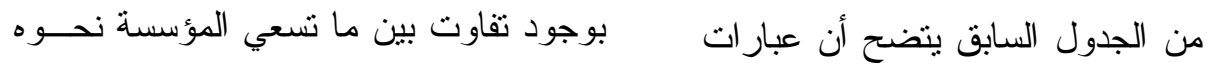

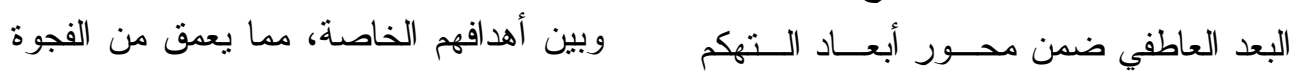

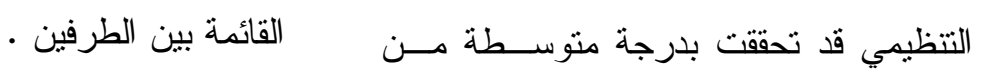

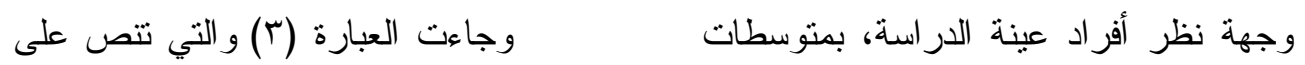

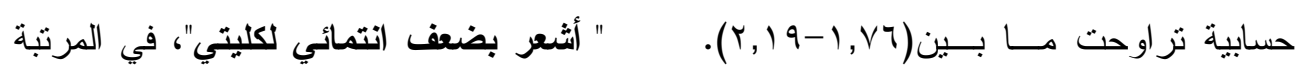

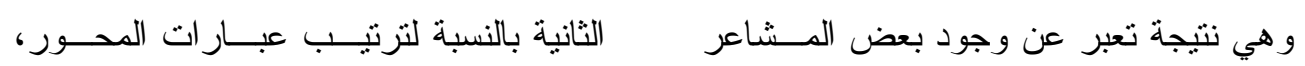

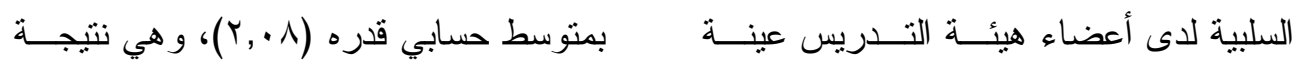

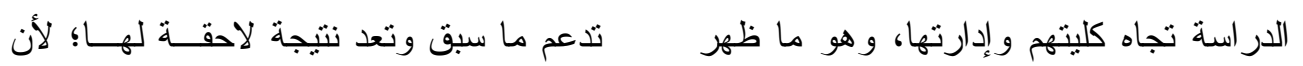

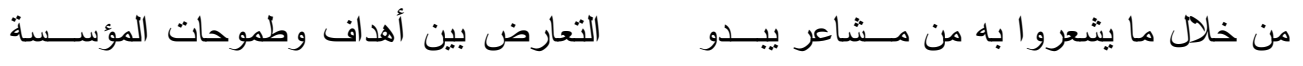
ومنسوبيها، يؤثر بالسلب على انتماء الأفراد

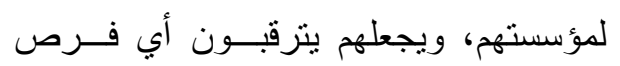
تسنح لهم لنركها ولو بصورة مؤقتنة. وفي المرتبة الأخيرة جاءت العبـارة بعضها سلبي تجاه مؤسستهم. كما يتضضح أن العبـارة ( () و التـي

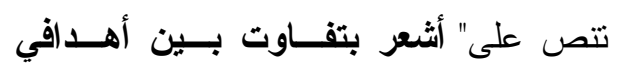

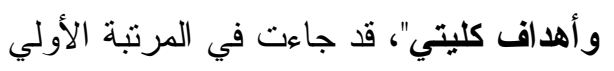

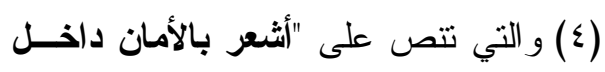

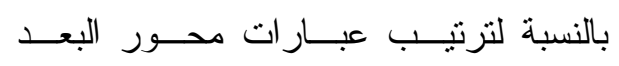

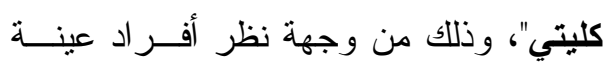

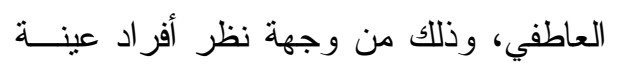

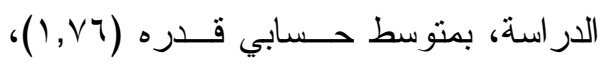

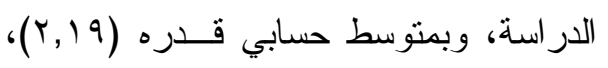

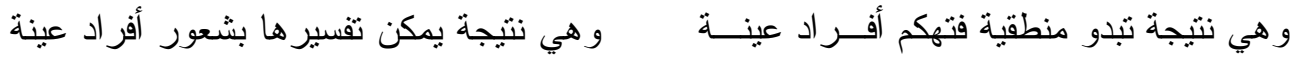

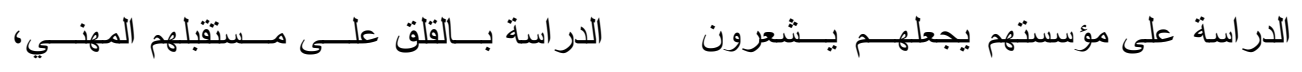


وهو ما دعمته نتائج در اســة(ســـر

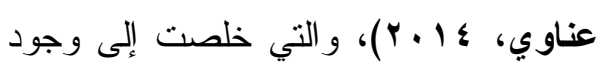

ارنباط إيجــابي بــين عدالــة الإجـــر اءات

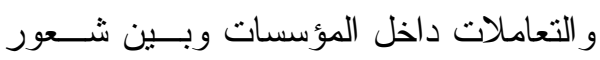

الأفر اد العاملين بالانتماء و الو لاء لمؤسساتهم،

و العكس صحيح.

أما فيما يتعلـــق بترنتــب عبــار ات

محور أسباب التهكم التتظيمي مسـن وجهــة

نظر أفر اد عينة الدر اسة فيوضحها الجــدول

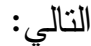

وتخوفهم لما قد يحدث كنتيجة طبيعية لوجود ما يدعو هم للتهكم التتظيمي داخل كلياتهم. وهي نتيجة نتفق مع ما أثنارت إلبــــ

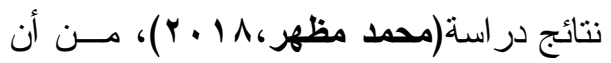

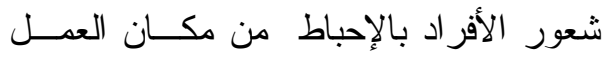

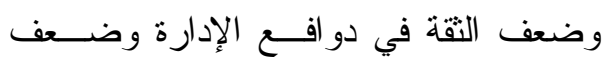
العلاقات الجيدة بين الموظف ورب العمــل نتيجة لشعور هم بانتهاك العقد النفسي من قبل

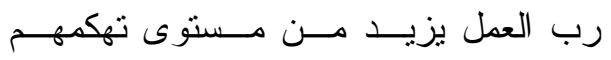

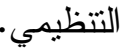

جدول(7)

ترتيب عبارات محور أسباب التهم التنظيمي من وجهة نظر عينة الدراسة

\begin{tabular}{|c|c|c|c|}
\hline الترتيب & المستوسط & عبار ات المحور & r \\
\hline الثاني عشر & $r, \cdot r$ & فنثل الكلية في تلبية توقعات الأعضاء و الوفاء باحتياجاتهم & 1 \\
\hline 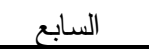 & $r, 1 \wedge$ & وجود تغيير مستمر في أساليب العمل داخل الكلية & r \\
\hline 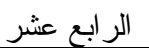 & $1, \vee 0$ & ضعف التعامل باحتر ام من جانب إدارة الكلية & r \\
\hline الثالث عشر & $1, \wedge 9$ & سو \& ظروف وتجهيز ات بيئة العمل داخل الكلية & $\varepsilon$ \\
\hline الثاني & r, $\varepsilon \cdot$ & زيادة مهام و أعباء العمل دون مقابل مادي أو معنوي & 0 \\
\hline 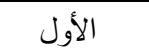 & r,, . & ضعف الر اتب مقارنة بما يبذل مع مهام و أعباء & 7 \\
\hline 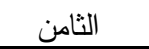 & $r, I V$ & تقليل إدارة الكلية لما بطر ح من أفكار ومبادر ات لتطوير العمل بها & $\mathrm{V}$ \\
\hline 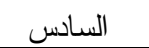 & $r, r$. & تقليل إدارة الكلية لما يبذل من مجهودات إضافية لتحسين الأداء & $\wedge$ \\
\hline 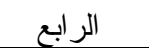 & r, & سبطرة النزعة الفردية في ممارسات عمل أعضاء هيئة التذربس بالكلية & 9 \\
\hline 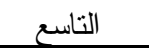 & $r, 17$ & ضعف الجانب الإنساني فيما بين أعضاء هيئة النكريس داخل الكلية & 1. \\
\hline 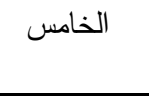 & Y, Y & وخارجها الزملاء بالكلية يميلون لإثارة المشكلات بصورة مستمرة داخل الكلية & 11 \\
\hline 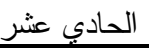 & $r, \cdot r$ & ضعف نقافة الحو ار و التفاهم فيما بين أعضاء هيئة التدريس وقيادات الكلبة & it \\
\hline 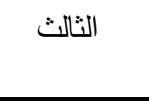 & t,rV & القتأثر إدارة الكلية بالوضعية الاعنبارية للأفراد عند اتخاذ وتطبيق بعض & IT \\
\hline 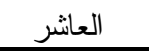 & $r, \cdot 9$ & ضعف الإحساس بالمسؤولية تجاه كليتي & $1 \varepsilon$ \\
\hline
\end{tabular}


سابقتها؛ حيث إن عــضو هيأسـة التـدريس بالأساس يشعر بضعف تقديره ماديًا ومعنويًا،

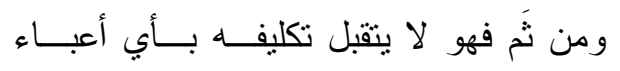

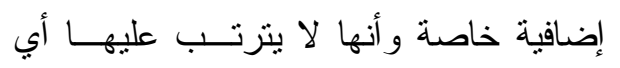

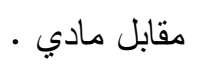
وفي المرتبة الأخيرة جاءت العبــارة (T) و التي تتص علــى " ضـــف التعامــل باحترام من جاتب إدارة الكلية"، وذلك مــن فئن

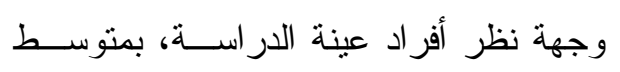

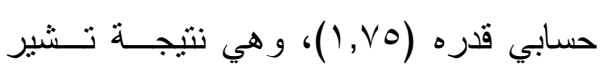
لتونر العلاقة بين أعضاء هيئة التدريس عينة الدر اسة وبين قيادات كلياتهم. وتتفق هذه النتيجة مع ما أثنارت إليه

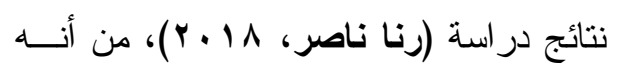

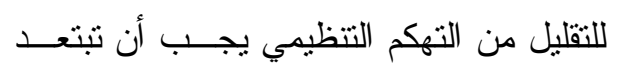

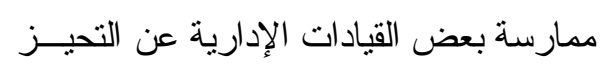

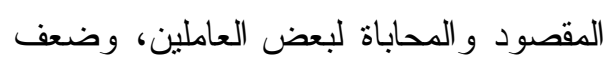

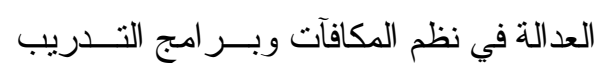

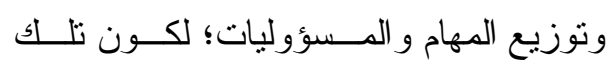

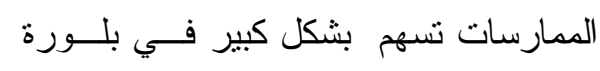
ظاهرة الــتهم التنظيهـي للعــاملين تجــاه مؤسستهم.

أما فيما يتعلق بترنيب عبار ات محور

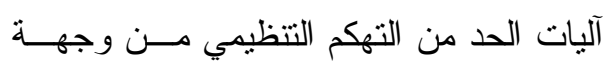
نظر أفر اد عينة الدراسة فيوضحها الجــدول التالي.
من الجدول السابق يتضح أن جميـع

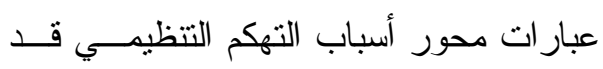
تحققت بدرجات متفاوتة من وجهة نظر أفر اد

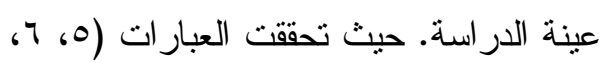

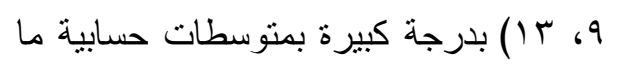

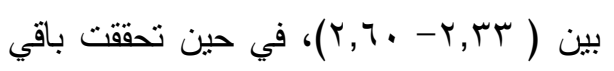

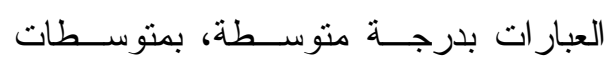

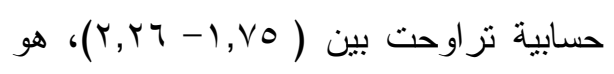
ما يشير لتو افق عينة الدر ساسة مـنـ أعـضناء

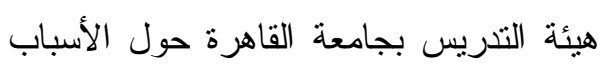

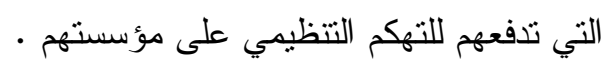

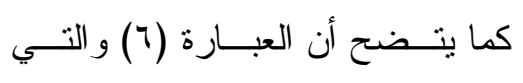
تتص على " ضعف الراتب مقارنة بما يبذل

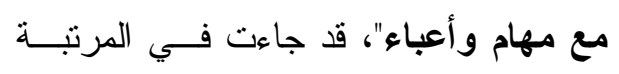

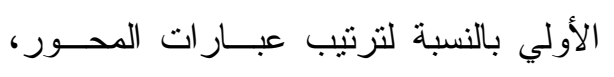

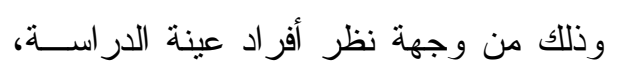

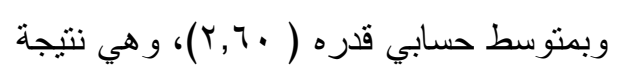

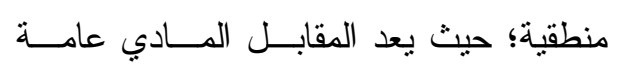

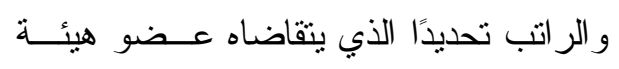

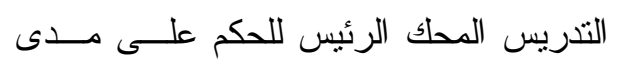
رضا عضو هيئة التدريس عـن مؤسـستها، وبالتالي ما يقوم به من واجبات ومسؤوليات. وجاءت العبارة (0) و الني تتص على

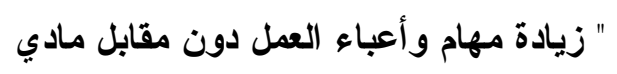

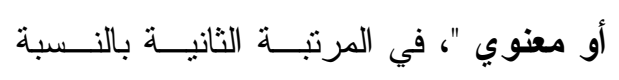

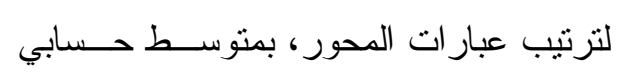

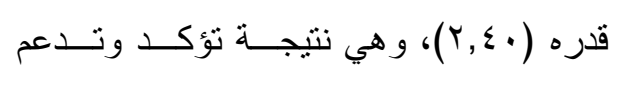




\section{جدول(v)}

ترتيب عبارات محور آليات الحد من التهم التنظيمي من وجهة نظر عينة الدراسة

\begin{tabular}{|c|c|c|c|}
\hline الترتيب & | المستوسط & 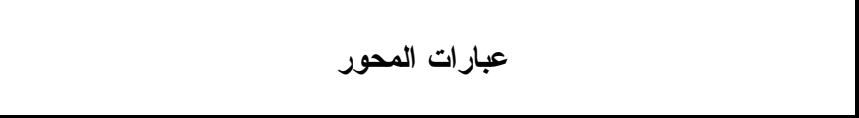 & b \\
\hline 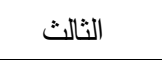 & r,Ar & تقريب المسافة بين إدارة الكلية وتوقعات الأعضاء و الوفاء باحتياجاتهم & 1 \\
\hline 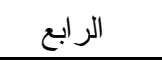 & $r, \Lambda)$ & تحسين مناخ وبيئة العمل المادية و المالية داخل الكلية & r \\
\hline 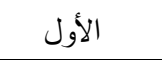 & $r, \wedge T$ & تثتجيع إدارة الكلية لما يقدمه الأعضـاء من أفكار تحسن الأداء & r \\
\hline 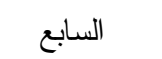 & $r, v V$ & تقدير إدارة الكلية لما يقوم به الأعضاء من مجهودات إضافية & $\varepsilon$ \\
\hline الثاني & $r, \wedge \varepsilon$ & لجهود الأعضاء وضو ومعايير واضحة ومعلنة لما تصرفه الإدارة من مكافآت طبقا & 0 \\
\hline 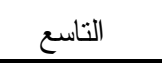 & r,vo & سرعة حل المشكلات الني تعترض الأعضاء أثناء العمل بصورة فورية & 1 \\
\hline 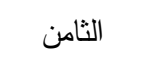 & r,vч & | وضوح التعليمات المصاحبة لأي قرار تتخذه إدارة الكلية & $\checkmark$ \\
\hline الثالث عشر & $r, \uparrow \Lambda$ & منح الأعضاء الصلاحيات الكافية لقيامهم بمسؤوليات أعمالهم & $\wedge$ \\
\hline 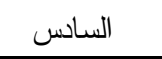 & $r, v \wedge$ & الالتز ام بالموضوعية و الثفافية عند معالجة المشكلات داخل الكلية & 9 \\
\hline الثامن عشر & $r, \pi$ & أدو ارهم بثكل أفضل الوضل المادية للأعضاء بما يكفل لهم حياة كريمة تمكهم من أداء & $1 \cdot$ \\
\hline الثاني عثر & $r, 79$ & تقوية العلاقات الإنسانية داخل الكلية لنقليل العزلة الاجتماعية & 11 \\
\hline 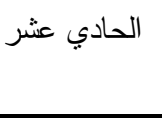 & $r, v)$ & و الأخذف بر أيهم صن صدمة فنل مبادرات التغيير بإنشر الك الأعضاء في تخطيطها & ir \\
\hline السابع عشر & $r, 7 \leqslant$ & تحقيق الاستجابة المتو ازنة للتعامل مع المطالب المتتو عة للأعضاء & ir \\
\hline 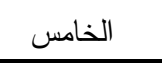 & $r, \vee q$ & تحقيق العدالة و المساو اة بين الأعضاء في المكافآت و التعاملات الثخصبة & $1 \leqslant$ \\
\hline 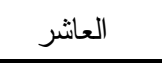 & $r, v r$ & إثثاعة ثقافة العمل الصادق و النز اهة و السلوك الأخلاقي بين الأعضاء & 10 \\
\hline 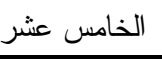 & $r, 74$ & | الترويج لجميع مبادرات التغيير التي نجتت بين الأعضاء & 17 \\
\hline 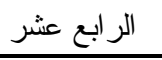 & r,TV & إقامة مجتمع جامعي يرفض الفساد ويؤمن بقيم العدالة و النز اهة و الثنفاقية & iv \\
\hline الساد عشر & $r, 70$ & توضيح دور كل عضو في تحقيق أهداف الكلية & 11 \\
\hline
\end{tabular}


وجاءت العبارة (0) و التي تتص على

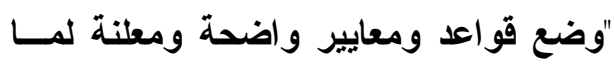

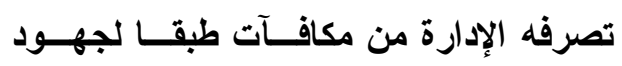

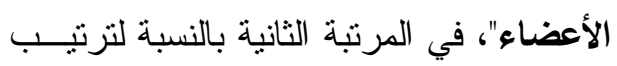

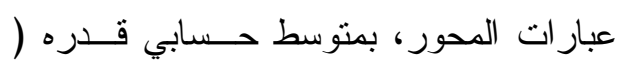

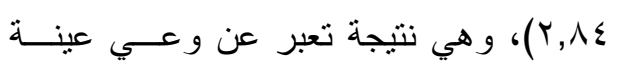

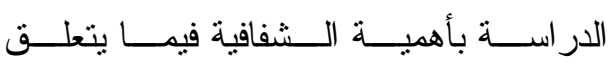

بالممارسات المالية للمؤسسة، كما أنها تتو افق بقأق

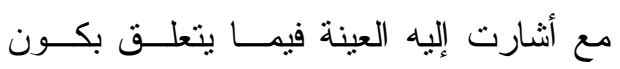

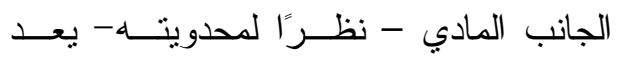
المحرك الرئيس لتهكم الأعضاء.

وفي المرتبة الأخيرة جـــاءت العبـارة

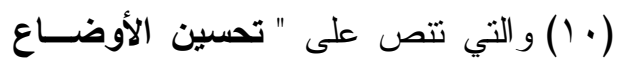

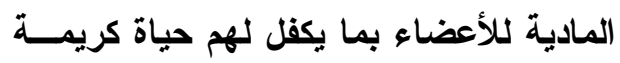

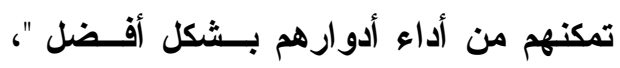

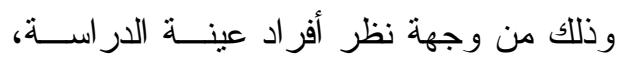

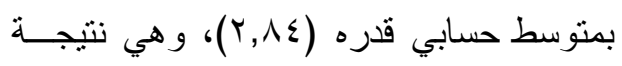

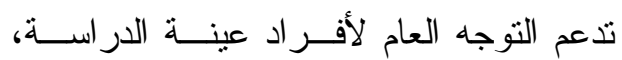

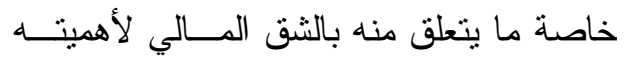

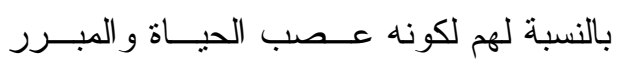

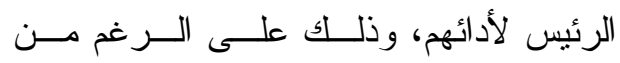
اقتتاعهم بأن إدارة كلياتهم لن تفعل الكثير في ولي

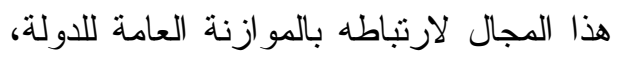

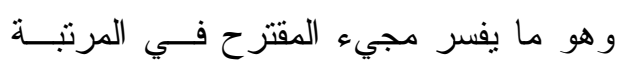
الأخيرة من وجهة نظر هم.

وتتفق هذه النتيجة مع ما أثنارت إليــــ

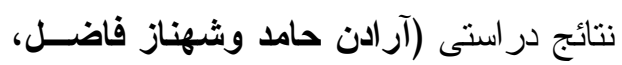

مــن الجــدول الــسابق يتــضح أن

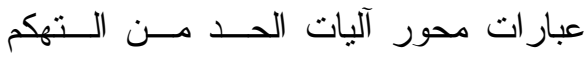
التتظيمي قد تحققت بدرجة كبيرة من وجهة

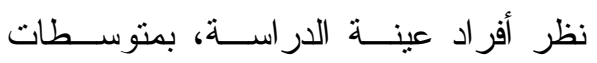

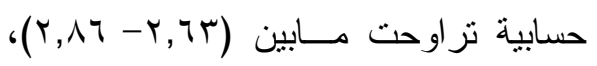
و هي نتيجة تشير لتو افق عينة الدراسة مــن أعضاء هيئة التذريس بجامعة القاهرة بشأن

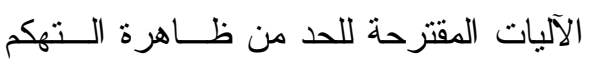
التتظيمي و التخفيف من آثار ها السلبية. كما تثير النتيجة لوعي عينة الدراســـة بأهميــة التحرك نحو معالجة المشكلة قبل أن تتفــاقم وتزداد أضر ار ها. كما بتضح أن العبــارة (ب) و التـي

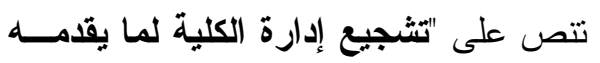
الأعضاء من أفكار تحسن الأداء"، قد جاءت

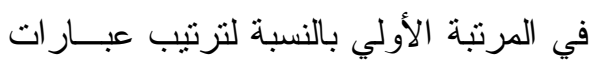

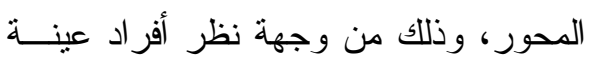

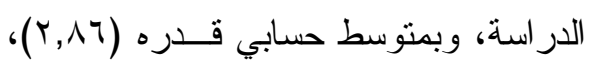
وهي نتيجة منطقية تدعم النتــائج الــسابقة الخاصة بمحور أسباب الــتهكم، و الأبعــاد

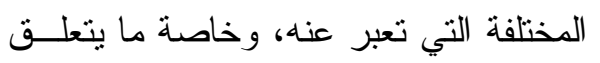

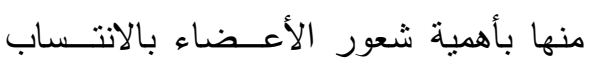

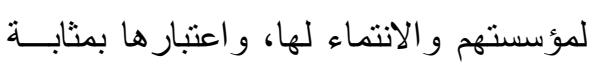

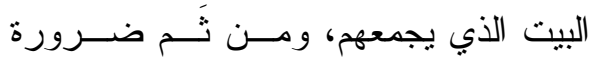
الالتفاف حوله وتقديم كل ما من شأنه رفعته فئه

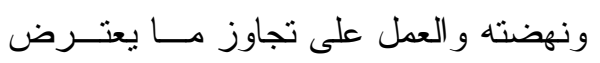
طريقهم من خلافات. 
- نطبيق الثفافية في اتخاذ القرار ات. - اختيــار الأعــضـاء الفــاعلين للأكـــاكن القيادية.

- توزيع العمل بالمـسـاو اة وفقَّا لمعــيير

$$
\text { و اضحة. }
$$

- القضاء على الفردية في العمل و إثــــاعة

$$
\text { استخدام التفويض. }
$$

- عدم التخبط في القرار ات وتغيير ها بشكل

$$
\text { مستمر • }
$$

- عقـــــــــــاءات شـــــرية بـــين الإدارة و الأعضاء لبحث المشكلات و العمل على لـ لاءلى

$$
\text { حلها. }
$$

- اختيار القيادات من الأعضاء بناء علــى

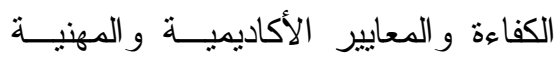

$$
\text { وليس تبعًا للمعارف و أهل الثقة. }
$$

- التأكيد علـى قـيم العدالـــة و الــشفافية

$$
\text { و النز اهة. }
$$

- تحسين الأوضاع المالية و المعنوية لبيئــة العمل.

أما عن أثز متغير ات الدراسة(الجنس،

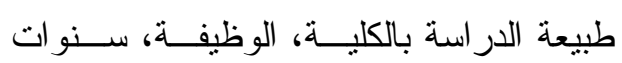

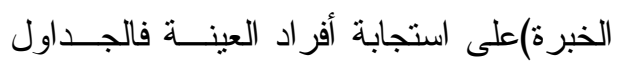
التالية توضح ذللك.

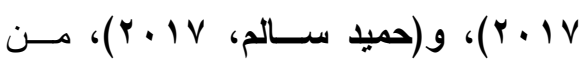

أهمية وجود آليات تخفف مسستوى الــتهكم

$$
\text { التتظيمي من خلال التركيز علــى الــدعم }
$$

التتظيمي و التو افق المهني لدى العاملين، بما لتركي

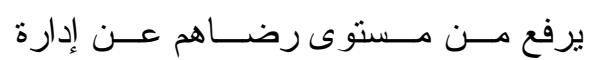

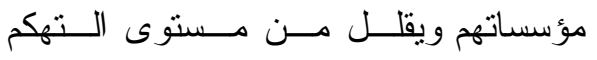

و السخرية كأثر سلبي غير مرغوب فيه ورلا

$$
\text { يخدم أهداف المؤسسة. }
$$

كما أنها نتائج نتو افق مع اســتجابات بعض أفر اد عينة الدر اسة بشأن مقترحساتهم

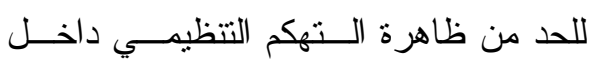
كليتهم ، حيث دارت أغلب مقترحاتهم حول: - ضرورة استخدام قدر ات أعضاء هيئــة

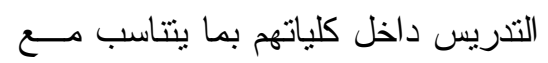
قدر اتهم وميولهم وخاصة في الأعمـال الإدارية من جودة وكنترو لات.

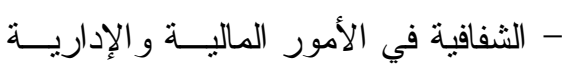
بالكلية .

- التعامل المهنــي مـــع أعــضاء هيئــة التنريس من قبل الإدارة بصرف النظر اعراء لهاء عن الأشخاص. - وضع آلية و اضحة ومعلنــة بالمعـايير

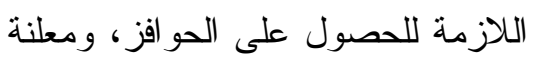
للجميع قبل تطبيقها. 


\section{جدول (^)}

أثر متغير الجنس على إجمالي استجابات أفراد الاراسة بالنسبة لمحاور الدراسة

\begin{tabular}{|c|c|c|c|c|c|c|}
\hline المعنوية & ح.د & قيمة ت & الاحعر اف & المسابي & الجنس & المحور \\
\hline \multirow[t]{2}{*}{$\cdots$} & \multirow[t]{2}{*}{$r \cdot r$} & \multirow{2}{*}{$-\varepsilon, \Sigma 9 \wedge-$} & .rNIOV & 1,7979 & ذكر & \multirow{2}{*}{ أبعاد التهكم التتظيمي } \\
\hline & & &.$\varepsilon \vee \ldots \varepsilon$ & $1,9 \vee \cdot 1$ & أنثي & \\
\hline \multirow[t]{2}{*}{. .11} & \multirow[t]{2}{*}{$r \cdot r$} & \multirow{2}{*}{$-r, r \wedge १-$} & $. T V \leqslant Y V$ & 1,9Уr० & ذكر & \multirow[t]{2}{*}{ أسباب التهكم التتظيمي } \\
\hline & & & $.50 \vee 09$ & r, ITr. & أنثي & \\
\hline \multirow[t]{2}{*}{$. r I \leq$} & \multirow[t]{2}{*}{$r \cdot r$} & \multirow[t]{2}{*}{$1, r \leqslant \wedge$} & .01947 & r,VAVT & ذكر & \multirow{2}{*}{ آليات الحد من التهكم } \\
\hline & & &.$r 9909$ & $r, v \cdot 11$ & أنثي & \\
\hline \multirow[t]{2}{*}{.0r } & \multirow[t]{2}{*}{$r \cdot r$} & \multirow[t]{2}{*}{$-1,9 \leq \vee-$} & .rVrqq & $r, r \leqslant r T$ & ذكر & \multirow[t]{2}{*}{ الإجمالي } \\
\hline & & & בTYMT. & T, TrOT & أنثي & \\
\hline
\end{tabular}

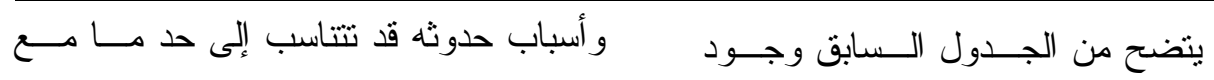

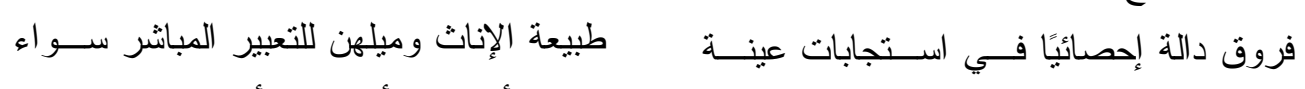

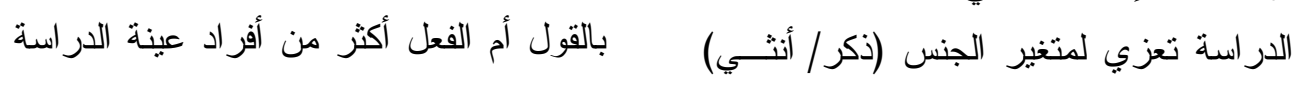

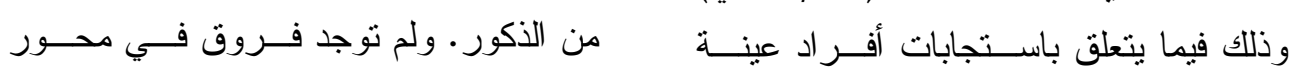

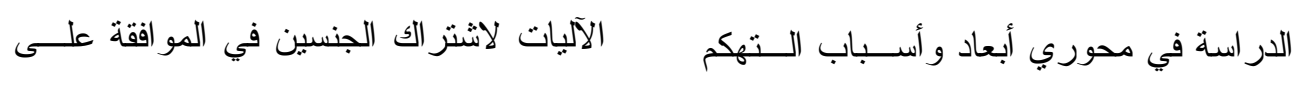

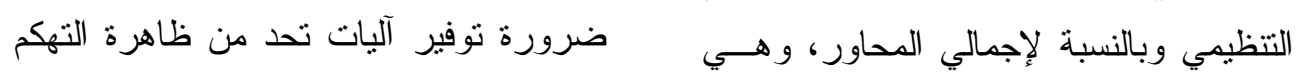

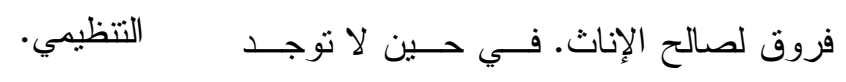

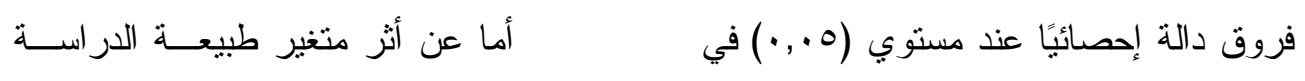

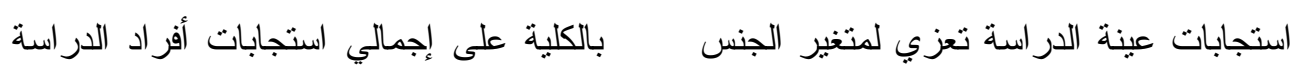

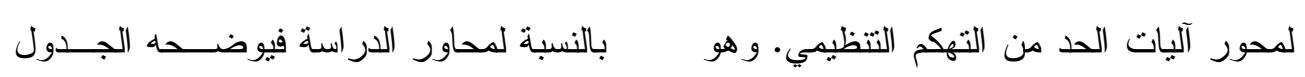
ما يمكن تفسيره من خلال كون أبعاد التهكم التالي.

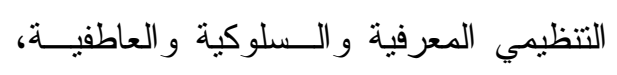


جدول(9)

أثر متغير طبيعة الار اسة بالكلية على إجمالي استجابات أفراد الدراسة

\begin{tabular}{|c|c|c|c|c|c|c|}
\hline المعنوية & د. & قيمة ت & الآحراف & الحسابي المتوسط & المشاركة & المحور \\
\hline \multirow{2}{*}{$\ldots$} & \multirow{2}{*}{$r \cdot r$} & \multirow{2}{*}{. } & . EOrIA & $1,91 \pi 1$ & نظرية & \multirow{2}{*}{ أبعاد التهكم } \\
\hline & & & س. & $1,79 r 0$ & عملية & \\
\hline \multirow{2}{*}{..$\leqslant 0$} & \multirow{2}{*}{$r \cdot r$} & \multirow{2}{*}{$\begin{array}{c}- \\
-r, .11\end{array}$} & $.0 Y \cdot V Y$ & $1,9 \wedge \vee r$ & نظرية & \multirow{2}{*}{ أسباب التهكم } \\
\hline & & & . TV. $\varepsilon r$ & $r, 100 r$ & عملية & \\
\hline \multirow{2}{*}{$\cdots$} & \multirow{2}{*}{$r \cdot r$} & \multirow{2}{*}{$\begin{array}{c}- \\
-r, q \leq \tau\end{array}$} & . T. $\leqslant Y T$ & & نظرية & \multirow{2}{*}{ آلتهات الحد من التتظيمي } \\
\hline & & &.$r q .7 \varepsilon$ & $r, q \cdot \wedge$. & عملية & \\
\hline \multirow{2}{*}{$.0 \mathrm{VT}$} & \multirow{2}{*}{$r \cdot r$} & \multirow{2}{*}{$-.077-$} & . EYYT. & T,YVYT & نظرية & \multirow[t]{2}{*}{ الإجمالي } \\
\hline & & &.$Y 1719$ & $r, r \ldots r$ & عملية & \\
\hline
\end{tabular}

يتوفر بها وقت لأفر اد عينتها تمارســه فـي لئي

يتضح من الجدول الــسابق وجــود

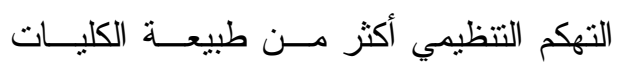

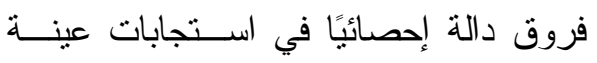

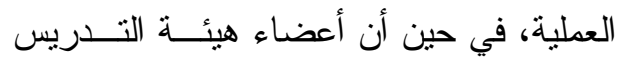

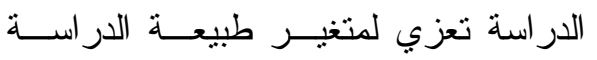

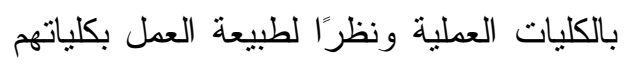

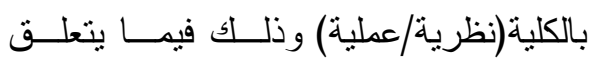

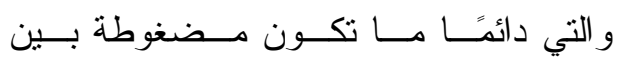

باستجابات أفراد عينة الدراسة في محسـور

المحاضر ات و المعامل و الجانب العملي أكثــر لئر

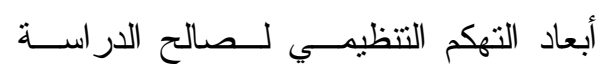

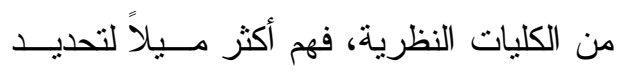

النظرية، ومحوري أسباب التهكم النتظيمـي لئي أسباب التهكم ووضع آليات تحد منه.

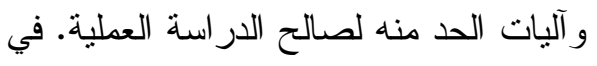

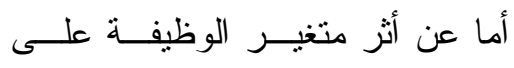

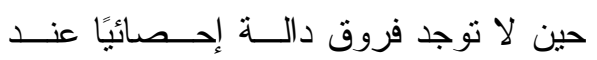

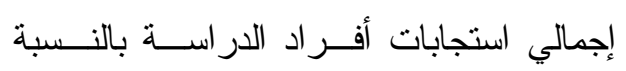

مستوي (0. . •) في استجابات عينة الدر اسة

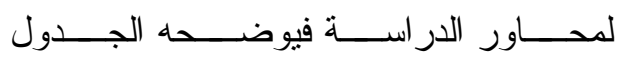

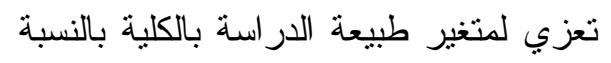
لإجمالي المحاور • و هو ما يمكن تفسيره من النالي.

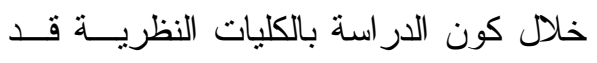




\section{جدول( · (1)}

تحليل التباين الأحادي لبيان أثر متغير الوظيفة على استجابات أفراد العينة

\begin{tabular}{|c|c|c|c|c|c|c|}
\hline المعنوية & قيمة ف & متوسط المربعات & د. & مجموع المر بعات & \multicolumn{2}{|c|}{ المحور } \\
\hline$\ldots r$ & $0,9 \wedge 9$ & $\begin{array}{l}1,1 \mathrm{KO}_{0} \\
.11 \mathrm{~N}\end{array}$ & $\begin{array}{l}r \\
r \cdot r \\
r \cdot \varepsilon\end{array}$ & $\begin{array}{l}r, Y O . \\
r V, q \leq V \\
\leq ., 19 V\end{array}$ & داخل المجمو عات المجموعات & أبعاد التهكم \\
\hline$\ldots$ & $r T, \leqslant 00$ & $\begin{array}{l}7, \vee \vee T 4 \\
. Y \wedge \Lambda\end{array}$ & $\begin{array}{l}r \\
r \cdot r \\
r \cdot \varepsilon\end{array}$ & $\begin{array}{l}\text { Ir,OHI } \\
\text { ON, YT7 } \\
V 1, V 91\end{array}$ & داخل المجموعات & أنتباب التنكيمي \\
\hline$\ldots$ & $I_{Y, V} \circ 9$ & 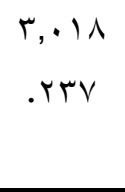 & $\begin{array}{l}r \\
r \cdot r \\
r \cdot \varepsilon\end{array}$ & $\begin{array}{l}\nearrow, \cdot r 4 \\
\varepsilon V, Y V Y \\
\text { Or,NIY }\end{array}$ & داخل المجموعات & آليات الحد \\
\hline$\ldots$ & $1 V, T \cdot \varepsilon$ & $\begin{array}{l}1,10 \leqslant \\
.1 .0\end{array}$ & $\begin{array}{l}r \\
r \cdot r \\
r \cdot \varepsilon\end{array}$ & $\begin{array}{l}r, v \cdot \Lambda \\
r, r v r \\
r \varepsilon, q \wedge .\end{array}$ & داخل المجموعات المجموعات & الإجمالي \\
\hline
\end{tabular}

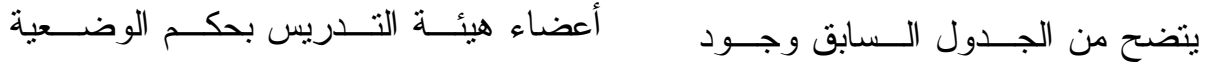

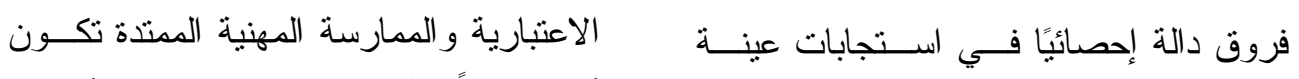
الدراسة تعزي لمتغير الوظيفة(مدرس/أستاذ أكثر إدر اكًا لأبعاد التهكم التنظيمي وأسبابه،

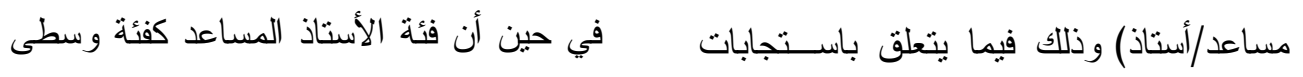

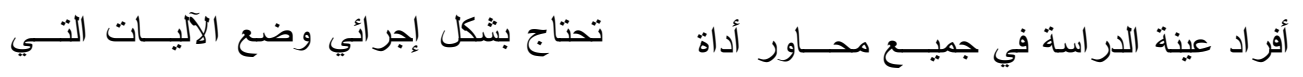

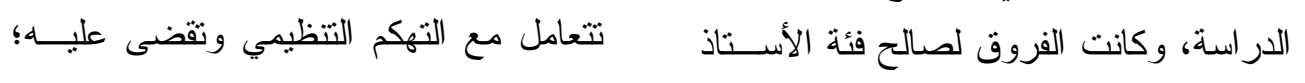

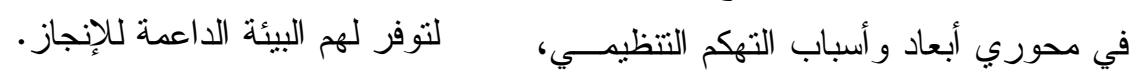
ولصالح فئة الأستاذ المساعد في محور آليات

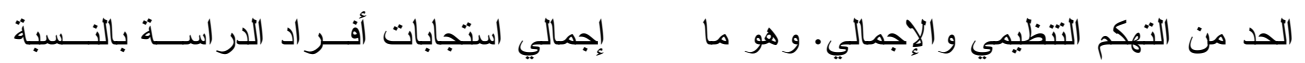

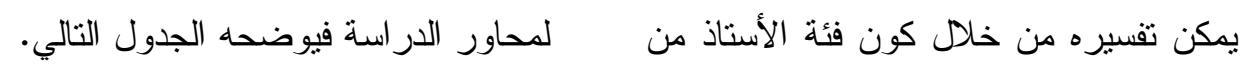


جدول(11)

تحليل التباين الأحادي لبيان أثر متغير سنوات الخبرة على استجابات أفراد العينة

\begin{tabular}{|c|c|c|c|c|c|c|}
\hline المعنوية & قيمة ف & متوسط & د.د & مجموع & \multicolumn{2}{|c|}{ المحور } \\
\hline$\ldots$ & $\wedge, \wedge q \curlyvee$ & 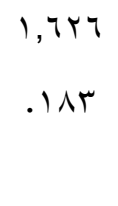 & $\begin{array}{l}r \\
r \cdot r \\
r \cdot \varepsilon\end{array}$ & $\begin{array}{l}r, r \circ r \\
r q, q \leq \varepsilon \\
\varepsilon \cdot, 19 \vee\end{array}$ & داخل المجمو عات المجموعات & أبعاد التهكم \\
\hline$\ldots$ & IT, & $\begin{array}{l}\varepsilon, 1.1 \\
.410\end{array}$ & $\begin{array}{l}r \\
r \cdot r \\
r \cdot \varepsilon\end{array}$ & $\begin{array}{l}\Lambda, r \cdot 1 \\
7 r, 097 \\
V 1, V 9 \Lambda\end{array}$ & داخل المجمو المجوعات & أسباب التنظميمي \\
\hline$. V \leq T$ & rq & $\begin{array}{l}. . V A \\
.474\end{array}$ & $\begin{array}{l}r \\
r \cdot r \\
r \cdot \varepsilon\end{array}$ & $\begin{array}{l}.104 \\
\text { Or,T07 } \\
\text { Or,NIT }\end{array}$ & داخل المجموعات المجوعات & آليات الحد \\
\hline..$\leq$ & $r, Y \vee \wedge$ & . & $\begin{array}{l}r \\
r \cdot r \\
r \cdot \varepsilon\end{array}$ & $\begin{array}{l}. V \wedge 0 \\
r \leqslant, 19 \varepsilon \\
r \leqslant, 9 \wedge .\end{array}$ & داخل المجمو عات & الإجمالي \\
\hline
\end{tabular}

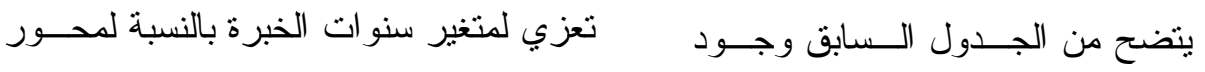

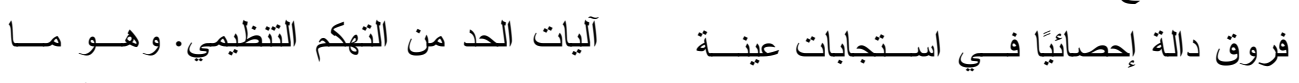

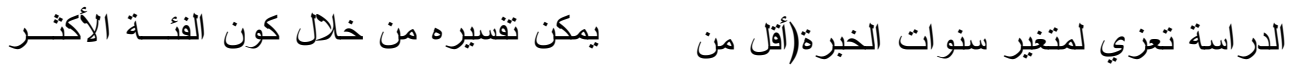

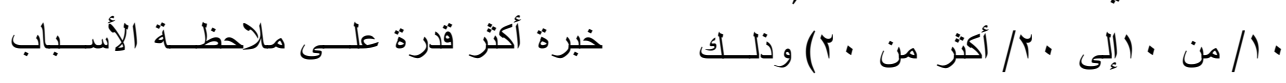

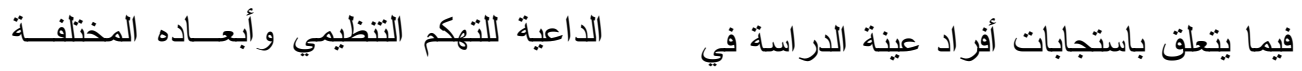

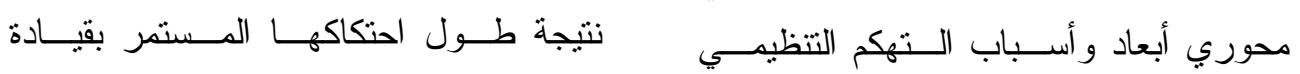

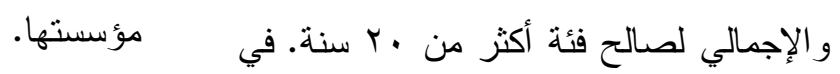

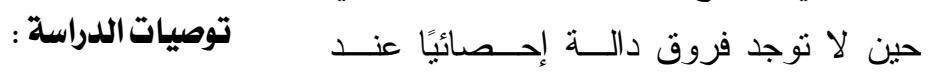

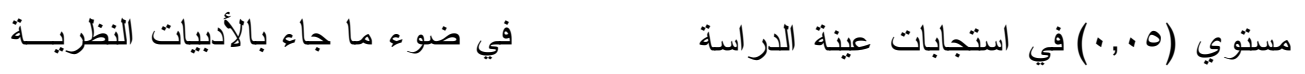

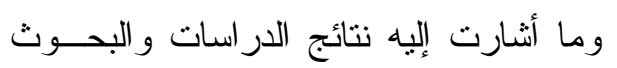


- ترسيخ مبدأ سياسة الباب المفتوح وعقد اجتماعات متكررة بـين إدارة الكليـات

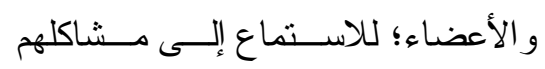
وشكو اهم للحد من السلوكيات المنحرفة و السلبية.

- توفير بدائل متتوعة لزيادة المخصصات المالية لأعضاء هيئة التدريس بالكليـات لترديات

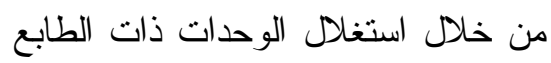
الخاص في تقديم خدمات بمقابل مــادي

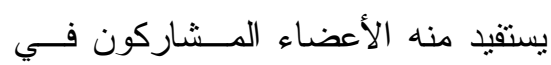

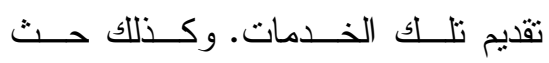
الأعضاء وتشجيعهم على المشاركة فـي لكي المشروعات البحثية الممولــة، وتــــليل

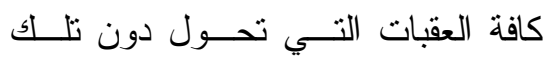
المشاركة ـ المهات

- حث الكليات على التوجه بشكل مباشــر وفعلي نحو التقليل من ظــاهرة الــتهكم

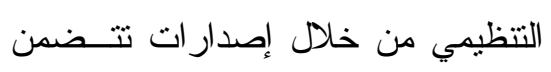

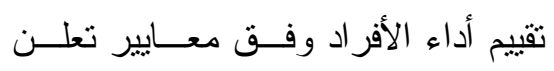

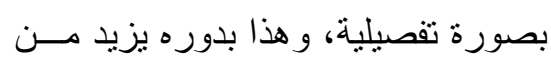
المشاعر الإيجابية نحو كليتهم من حيث توزيع المكآفات المادية و المعنوية، فضلاًا

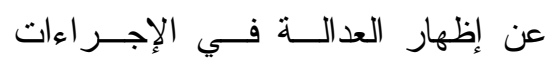

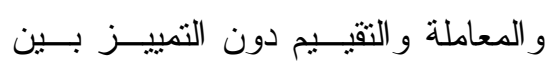
الأعضاء من خلال الأداء .

- خلق الانسجام و التتاغم بين أعضاء هيئة

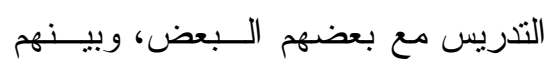

السابقة التي نتاولت التهكم التنظيمي وعلاقته

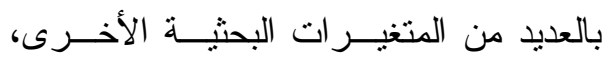

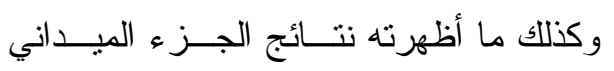
المطبق على عينة من أعضاء هيئة التذريس

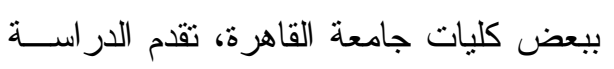
بعض النوصيات و المقترحات الني من شأن

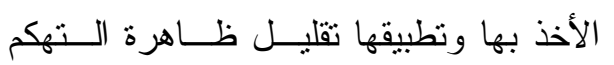

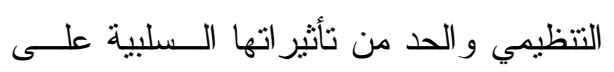
الكليات و الأعضاء العاملين بها: - إثر الك أعضاء هيئة التدريس في عملية

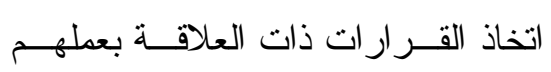

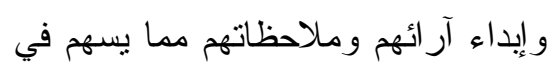

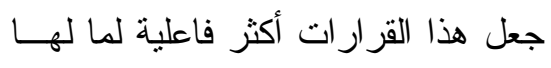

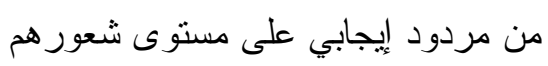
بعدالة الإجر اءات. - إيمان قيادات الكليات بأن الـــدعم الــــي

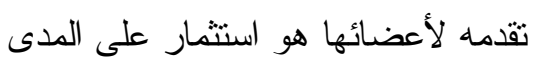

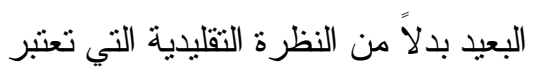

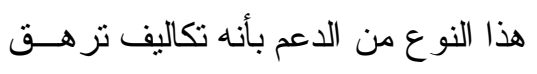
ميز انياتها. - مذان - تأمين بيئة عمل تتسم بعدالـــة العمليــات و الإجر اءات، وتقديم المكافآت للأعضاء

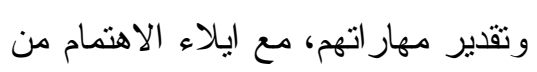

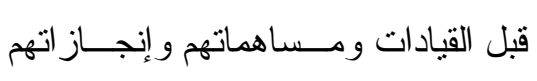
بهدف دعمهم تتظيميًا. 
- ضرورة النظر إلى أعضاء هيئة التنريس بالكليات بأنهم الأساس الذي تعتمد عليه

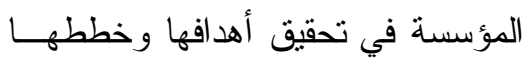

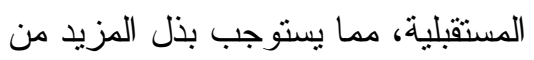

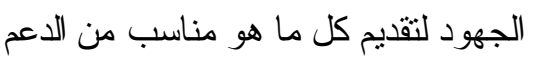
التظيمي - ضرورة أن تدرك عمادة الكليات ورؤساء الأقسام أن التهكم التتظيمـي يمكـن أن أن

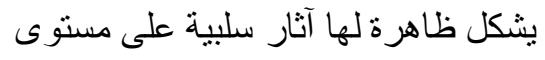
الكلية وقد تقود بالأعضاء إلــى انتهـــاج

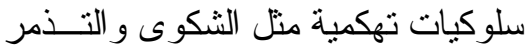
و الانتقاد الأمر الذي يؤدي إلى فــثل أي لـي

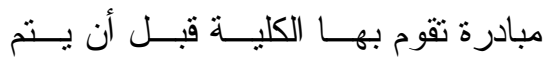
تطبيقها - ضرورة أن تعكس الممارسات و الأنشطة التي تؤديها الكليــات تجـــاه أعــضـائها المصداقية و العدالة وبما يــدعم زيــادة

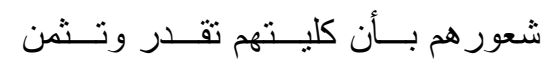

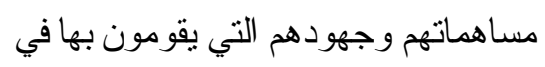
العمل، و العمل فـــي توجيـــه القبــادات بوجوب المصداقية في الأقو ال و الأفعال

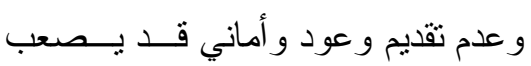

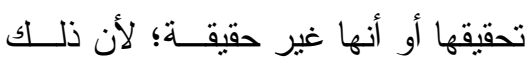
ينعكس بشكل و اضح في زيادة مسستوى

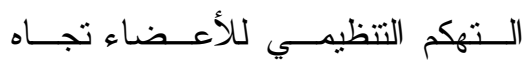
مؤسستهم.
وبين ورؤساء العمل باتباع سياسة الباب

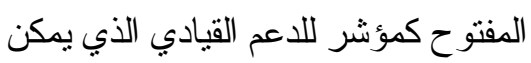

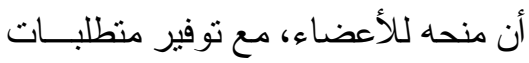
إنجاز العمل المادية و هذا يعتبر مؤشــرًا

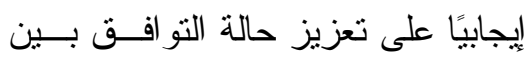
الوظيفة وشاغلها. - دعم قيادة الكليات لمجموعة الأفكار التي يحملها الأعضاء حـــول التــز ام الإدارة بمجموعة من المبادئ الأخلاقية المقبولة، وذلك من خلال التعامل بشفافية وتقــديم الحقائق كما هي، و الابتعاد عن التحيز في القضايا العامة و التعامل بصدق ونز اهة مع الأعضاء، و التعاون معهم في تجاوز

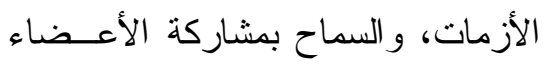
بأفكار بناءة ووضع لأحمة مبادئ ولئح بمكن أن تكون مرشدًا للقيادات. - ضرورة اعتماد الكليات على بر امج قابلة للنطبيق وفقًا لآليات معينة من أجل نقليل

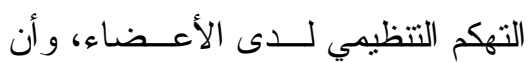
تعمل بما ينسجم مع أهدافها وسياســتها المرسومة من قبلها. - ضرورة العمل على ترسيخ ثقافــة روح

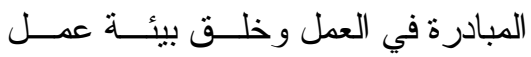

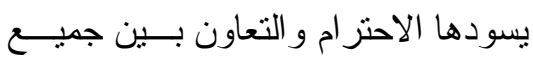
الأعضاء إذ أن ذلك يجعل الأعضاء أكثر

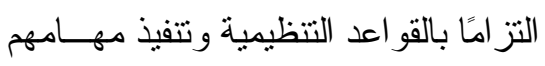


التتظيمي بحث ميداني لآر اء عينة مـن

العاملين في ديوان وزارة الثباب، مجلة

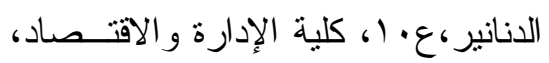

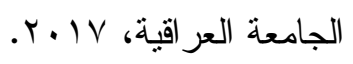

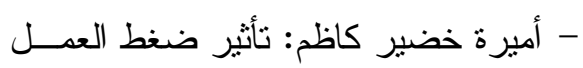
في التهكم التنظيمي در اسة اســنطلاعية

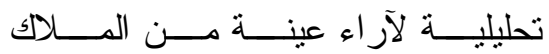
التمريضي في مشفي الصدر التعليمسي لـي في محافظة النجف، المجلـــة العراقيــة

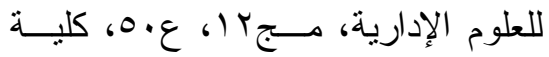

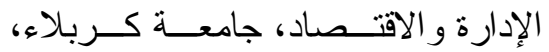

- بسام سمير الرميدي: أثز نطبيق نمطـي

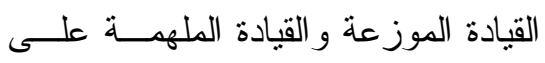

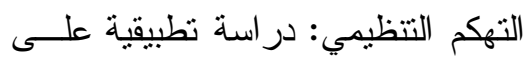
شركات السياحة المصرية، مجلة اقتصاد

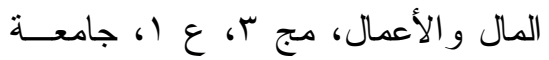
الو ادي، الجزائر، مارس 9 1 ـ ب. - بن زروال فتيحة: الإجهاد على مستوى

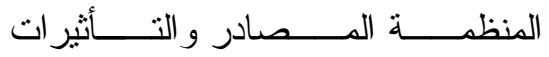
و استر اتيجيات المو اجهة، در اسات نفسية وتربوية،ع ع، جامعة قاصدي مربـــاح

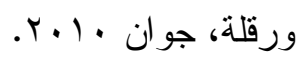

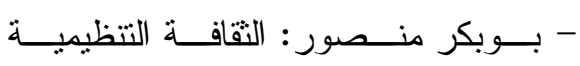

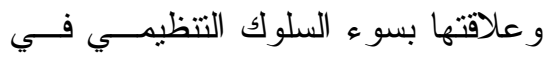

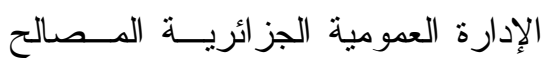

- ضرورة بناء مناخ يدعم وجــود ثقافــة الصدق و النز اهة و السلوك الأخلاقي بين الأعضاء داخل كلياتهم و استخدام التغذية ولية العكسية لتخفــيض مـستويات الــتهكم

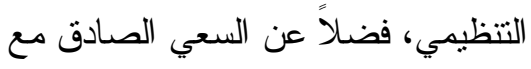
ايصال فكرة هذا السعي إلى الأعضاء في لئي

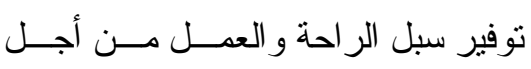
المجموعة لا من أجل التقرد أو التحزب. - ضرورة تشجيع قيادات الكليات لــروح المنافسة بين الأعــضاء وتميـز الأداء

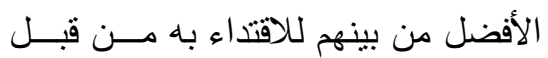
الآخرين الآطن من

- ضـــرورة قيــام إدارة المؤســسات اللتعليمية/الكليات بالعمل على تعزيــز اهتمامها بـسمعتها وصــورتها أمــام

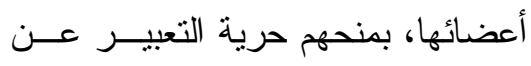

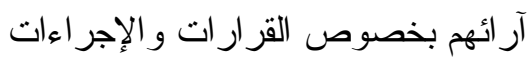
المتعلقة بمستقبلهم المهني لضمان تحقيق حالة التو افق و التـــوازن بــين إثـــباع حاجاتهم التي يتوقعون الحصول عليها في العمل و الاستجابة لمتطلباتهم، لما لـــللك من تأثير في تقليـلـل مـستوى الــتهكم التنظيمي لديهم.

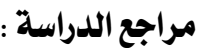

- آر ادن حامد خــضير وشــــناز فاضـلـل أحمد: الدعم التتظيمي المدرك و التو افق المهني و أثز هما في خفض ظاهرة التهم 
- سحر عنــاوي رهيـــو : دور العدالــة

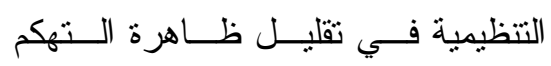
التتظيمي در اسة تحليلية لآراء عينه من منتسبي كلية التزبية جامعـــة القادســية،

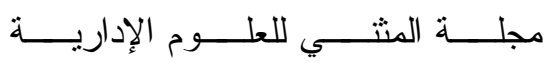

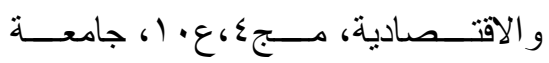

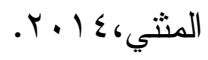

- شوقي محمد الصباغ و آخرون: نمــوذج مقترح لمشاركة العــاملين فــي صـــنع كمتغير وسيط في العلاقة بــين صـــوت

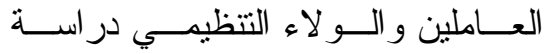
تطبيقية على أعضاء هيئـة التمــريض بمستشفيات جامعــــة المنوفيــة، مجلــــة

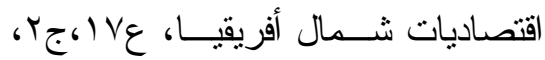
$. T . I V$ - عامر علي حـسين العطــوي: تفـسير ظاهرة التهكم التتظيمي في المنظمات من

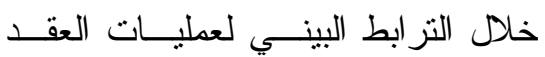
النفسي و الاحتر ام الداخلى در اسة تحليلية لآراء عينة من العاملين في معمل سمنت المثتي، مجلة القادسية للعلوم الإداريــة والاقتصادية، مجء (، عr، كلية الإدارة و الاقتصاد، جامعة القادسية، Y I . r. : طبيعة و أسباب الــتهكم التتظيمي بين الموظفين العر اقيين: دراسة تجريبية حقلية باستخدام الــسيناريو هات، المجلة العربية للعلوم الإدارية، مج سب،
الخارجية للدولة بولاية الو ادي نموذجًا،

رسالة ماجستير غير منــشورة، كليــة

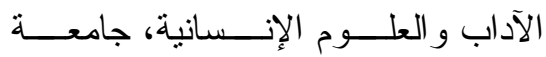

$$
\text { منتوري قسنطينة، V. . . . . }
$$

- جامعة القــاهرة : النــشرة الإحــــائية

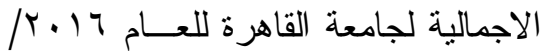

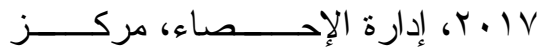
المعلومات و التوثيق، جامعـــة القـــاهرة، .$r .19$

: الدراسة الذاتية لجامعــة

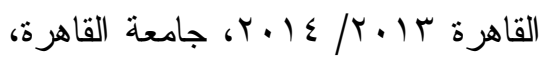
.r. I - حمبد سالم غياض : دور الدعم التتظيمي المدرك في تقليل التهكم التنظيمي در اسة تحليلية لآر اء عينة من التدريسيين فـي كلية الر افدين الجامعـــة، مجلـــة الإدارة

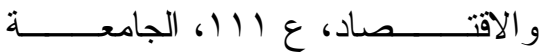

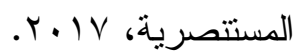

- رنا ناصــر صــبر : انعكــاس الـتهكم التتظيمــي علــى الــسلوك المنحــرف للعاملين بحث استطلاعي لآراء عينة من العاملين في الشركة العامة للــصناعات الصوفية، مجلة تكريت للعلوم الإداريــة و الاقتصادية، مجء؛، عءء؛، جن، كليــة

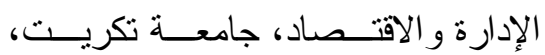
.$r \cdot 11$ 
عمادة البحث العلمي، جامعة الـسودان

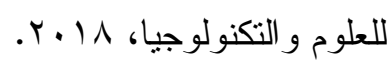

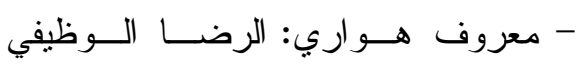
وعلاقته بهجرة الأطباء من المستشفيات الروات الجزائرية دراســة ميدانيــة بـــالمركز

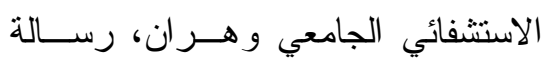

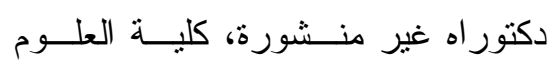

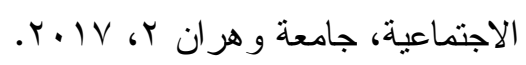
- منصور زاهي : الــشعور بــالاغتراب

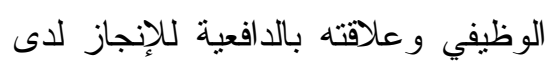

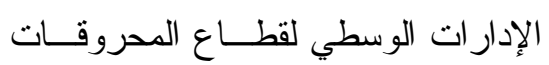

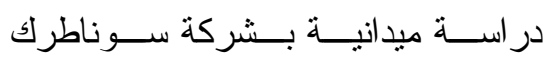
بالجنوب الجزائري، رسالة دكتور اه غير لئر

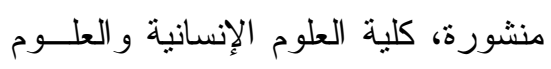

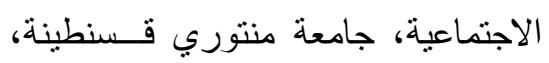
. r... - موزة حمود علي المعمريــة: ضـــوط

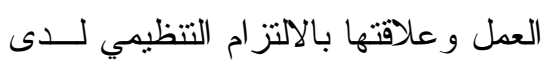

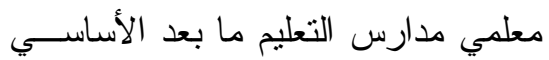

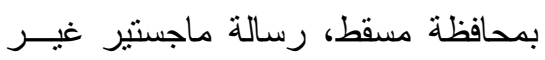

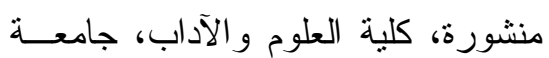

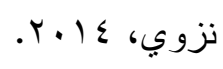
- ميثاق هاتف الفــتلاوي: دور الانغـــراز الوظيفي في تقليل سلوك التهكم التنظيمي

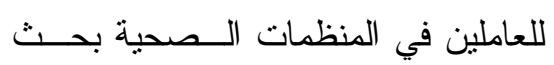
تحليلي في دائرة صحة كربلاء، المجلـــة
عَ، مجلس النـشر العلمـي، جامعــة الكويت، 17 . r ـ

- عبدالحكيم أحمد ربيع و آخرون: العلاقة

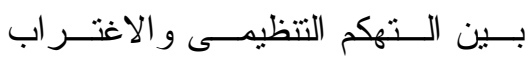
الاجتماعى : در اسة تطبيقية على أعضاء

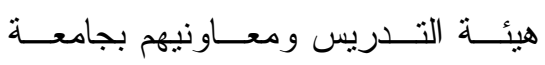
المنصورة، المجلة المصرية للار اســات

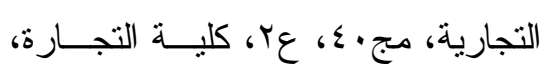
جامعة المنصورة، 17 . 17 .r. - علاء فرحان طالب و آخــرون: تـأثثر التهكم نحو التغيير التنظيمي في سلوكيات

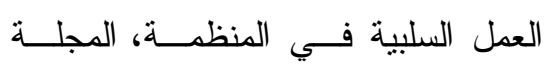

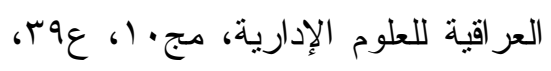

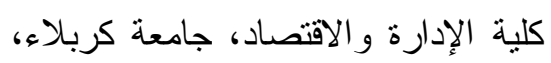
.r. $1 \leq$ - عمار فتحــي موســي إســماعيل: دور

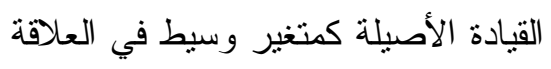

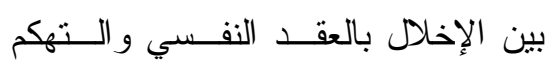
التظظيمي دراسة تطبيقية، مجلة البحوث

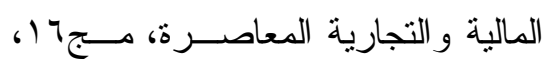

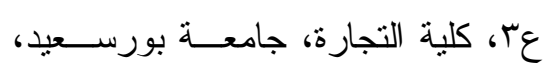
.$r .10$ - محمد مظهر مزعـلـ : أنـــر الــتهكم

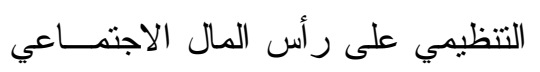

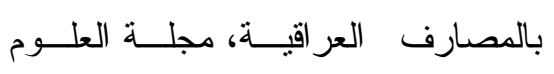

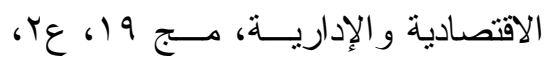


- Ali Riza Terzi \& Ramazan Derin: Relation between Democratic Leadership and Organizational Cynicism, Journal of Education and Learning,Vol.5, No.3, Canadian Center of Science and Education, 2016.

- Cagdas Caz \&Sait Bardakci: Relationship between academicians' organizational identification levels and cynicism attitudes in sports sciences. European Journal of Educational Research ,vol. 8,no.1,2019.

- Delken, M. :"Organizational Cynicism: A Study Among Call Centers (Dissertation)", Faculty of Economics and Business Administration, University of Maastricht, Maastricht,2004.

- Engin Karadag \& etal : Organizational Cynicism, School Culture, and Academic Achievement: The Study of Structural Equation Modeling, Educational Sciences: Theory \& Practice, vol.14,no.1, Educational Consultancy and Research Center,2014.

- Faruk Levent \& Sitar Keser: Examining the organizational cynicism among teachers at schools: A mixed methods study, Educational Research

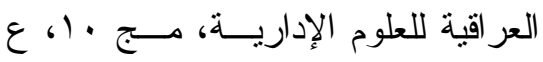

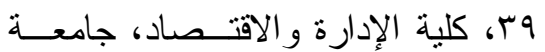

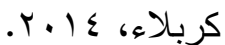

$$
\begin{aligned}
& \text { - نجوي متولي كثكوشة: تحليل المسـسار }
\end{aligned}
$$

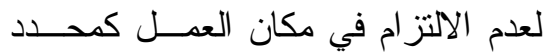

$$
\begin{aligned}
& \text { للرضا الوظيفي، المجلة العلمية لقطــاع }
\end{aligned}
$$

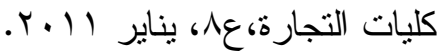

$$
\begin{aligned}
& \text { - هادي عبدالوهاب الابرو و الحمزة ماللك }
\end{aligned}
$$

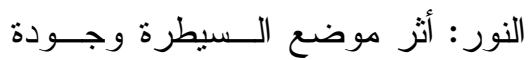

$$
\begin{aligned}
& \text { العلاقة في سلوك العمل المنحرف مــن مون } \\
& \text { خلال الثقة في القائد و التمكـين النفـسي: } \\
& \text { در اسة تطبيقيــة علــى العــاملين فــي } \\
& \text { مستشفيات البصرة الحكوميــة، المجلــــة }
\end{aligned}
$$

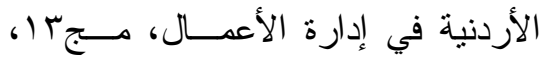

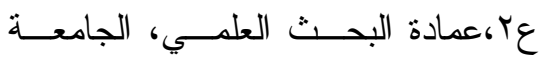

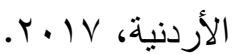

- Ahmed. W\& et al: "the study on organizational cynicism, organizational injustice and breach of psychological contract as the determinants of deviant work behavior", Actual Problems of Economics, Vol.2, No.140,2013.

- Ali Korkut \&Mahire Aslan: Organizational Cynicism levels of Teachers in Secondary Schools in Turkey, Einternational Journal of Educational Research, vol.7, issue 2,Agust.2016,p95. 


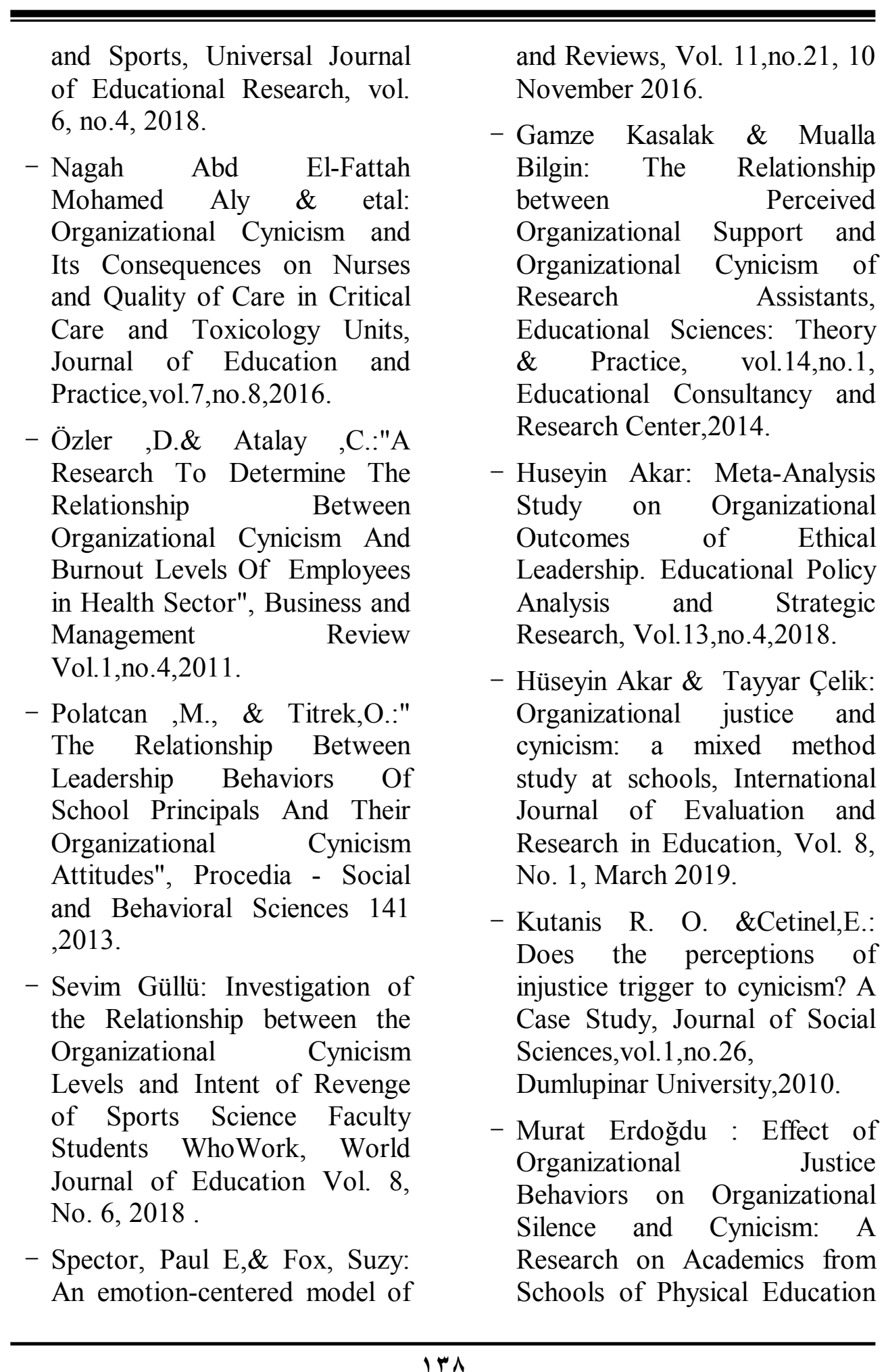


Levels, Eurasian Journal of Educational Research, Issue 63, 2016.

- Yeliz Eratlı Şirin \& et al: Transformational-Transactional Leadership and Organizational Cynicism Perception: Physical Education and Sport Teachers Sample, Universal Journal of Educational Research,vol. 6,no.9,2018. voluntary work behavior: Some parallels between counterproductive work behavior and organizational citizenship behavior), Human Resource Management Review, Vol.12, Issue 2, Summer 2002.

- Sultan Bilge \&Ebru Oguz : Relationship between Political Discrimination Level Perceived by Teachers and Teachers' Organizational Cynicism 